Amasya Ilahiyat Dergisi - Amasya Theology Journal

ISSN 2667-7326 | e-ISSN 2667-6710

Haziran / June 2019, 12: 373-408

\title{
Kilise, Mistisizm ve Feodalite Perspektifinden Orta Çağlı Bir Hıristiyan Mistik: Bingenli Hildegard*
}

\section{A Christian Mystic in the Middle Age: Hildegard of Bingen -From Perspective Church, Mysticism and Feodality}

\author{
Halil Temiztürk \\ Dr., Trabzon Üniversitesi İlahiyat Fakültesi, \\ Dinler Tarihi Anabilim Dalı \\ Dr., Trabzon University, Faculty of Theology, \\ Department of History of Religion \\ Trabzon, Turkey \\ haliltemizturk@gmail.com \\ orcid.org/0000-0002-4564-5561
}

\section{Makale Bilgisi / Article Information}

Makale Türü / Article Types: Araştırma Makalesi / Research Article

Geliş Tarihi / Received: 28 Aralık / December 2018

Kabul Tarihi / Accepted: 6 Mart / March 2019

Yayın Tarihi / Published: 15 Haziran / June 2019

Yayın Sezonu / Pub Date Season: Haziran / June

Sayı / Issue: 12 Sayfa / Pages: 373-408

Atıf / Cite as: Temiztürk, Halil. "Kilise, Mistisizm ve Feodalite Perspektifinden Orta Çağlı Bir Hıristiyan Mistik: Bingenli Hildegard [A Christian Mystic in the Middle Age: Hildegard of Bingen -From Perspective Church, Mysticism and Feodality]". Amasya İlahiyat Dergisi-Amasya Theology Journal 12 (June 2019): 373408.

https://doi.org/10.18498/amailad.579996.

* Makale, "Bir Mistik Olarak Hildegard ve Hıristiyan Düşüncesindeki Yeri” başlıklı doktora tezimizden üretilmiştir. This article is extracted from my doctorate dissertation entitled "Hildegard of Bingen and her Place in History of Christian Mysticism". 
374 | H. TEMIZTÜRK / Kilise, Mistisizm ve Feodalite Perspektifinden Orta Çağlı Bir Hiristiyan Mistik: Bingenli Hildegard

İntihal / Plagiarism: Bu makale, en az iki hakem tarafından incelendi ve intihal içermediği teyit edildi. / This article has been reviewed by at least two referees and scanned via a plagiarism software.

Copyright $\odot$ Published by Amasya Üniversitesi, İlahiyat Fakültesi / Amasya University, Faculty of Theology, Amasya, 05100 Turkey. All rights reserved. https://dergipark.org.tr/amailad.

\title{
A Christian Mystic in the Middle Age: Hildegard of Bingen -From Perspective Church, Mysticism and Feodality
}

\begin{abstract}
From the Middle Ages, Christian Mysticism has begun to mature. Living in that period, Hildegard of Bingen (1098-1179) can be seen as a remarkable figure when her mystic character is taken into consideration. She has influenced Christianity until today with her extraordinary visions and different works such as God, man, cosmology, music, botany and anatomy. Thanks to her visions, Hildegard is accepted as a consultant or an oracle by the people around her. In addition, she travels to different cities to preach to people and priests, and in these sermons she both criticizes the clergy in some aspects and warns people against heretic movements. What makes Hildegard different is that to describe some of God's attributes in a feminine way, to explain nature, God's attributes and virtues in a connection with each other manner. In this article will be eliminated life of Hildegard who is remarkable mystics in Christian mysticism history and her effect to Christian mysticism.
\end{abstract}

\section{Summary}

Hildegard of Bingen is a mystic lived in the Middle Ages (1098-1179). Even though Hildegard spent most of her life in the monasteries, she did not stick within the limits of the monastery. Because she intimated close relationships with many important people from the Pope to the Emperor. Hildegard has an important place in the history of Christian mysticism in terms of receiving the title of Church Doctor immediately after his death (1204). The Bingen region, where Hildegard lived, is included in the World Cultural List by UNESCO. This region is regarded as a pilgrimage and spiritual journey centre by the Christians. In this article, which is compiled from my doctorate dissertation entitled "Hildegard of Bingen and her Place in History of Christian Mysticism", we try to examine in this article, which is compiled from my doctorate dissertation entitled 
"Hildegard of Bingen and her Place in History of Christian Mysticism", we try to examine the life of Hildegard and influence of her on Christian mysticism.

The article focuses on the Church, mysticism and women's issues. First of all, will be informed brief information about Christian mysticism and Hildegard studies, then will be evaluated her effects on Christian thought.

Christian mysticism and the studies of Hildegard of Bingen were affected negatively by criticisms that began against religious ideas in the postEnlightenment period. However, Hildegard's work has increased in the West since the 90s. Additionally there has been made a film about her (Vision, y. 2009), Christians has accepted monasteries where she lived as the center of pilgrimage and has performed her compositions in church ceremonies. All of these demonstrate that Hildegard's position in Christian thought.

On the one hand in the period when Hildegard lived there occurred social and economic transformations on the other hand political and religious matters were debated in the center of the papal elections. We can say that Hildegard partly involved in these discussions. According to sources, Hildegard was born in 1098 as the tenth child of her family in a place known as Bermersheim in the diocese of Mainz. This area is surrounded by monasteries which follow different rules such as Benedictine and Cistercian. Hildegard with Jutta who is a spiritual leader (Magistra) of her and the other woman called Jutta cloistered to the Saint Disibod monastery. She remained in this monastery for many years, then moved to St. Rupert monastery, where she founded a convent dedicated to women. The approval of Hildegard's visions at the Trier Synod by Pope Eugenius accelerated the process of this move. Because the number of nuns of the monastery increased after this event. The monastery of Saint Disibod was recognized as the place of pilgrimage by the nuns and as a place of healing by the sick people.

The process from 1151 to her death was Hildegard's most influential period. Because Hildegard, who completed her most famous work Scivias, was known as a visionary mystic woman and priest. During this period, Hildegard got the opportunity to preach to priests and the public in sermons tours. In these sermons, Hildegard followed a policy defending the Church against separations and external dangers like Cathars even if she had not given them by name. Another issue that Hildegard emphasizes in her sermon tours is the laziness and weakness of the priests. The fact that a woman in her sixties age addressed to priests and rebuked for their mistakes is unordinary in terms of the dynamics of the Middle Ages. 
376 | H. TEMIZTÜRK / Kilise, Mistisizm ve Feodalite Perspektifinden Orta Çağlı Bir Hıristiyan Mistik: Bingenli Hildegard

Hildegard contributed to the history of Christianity and mystical Christian literature with her works and effectiveness. Hildegard is a mystic who works interdisciplinary with her many works belonging to different fields such as theology, mysticism, herbal medicines, natural philosophy. Also, the church music, which is composed by Hildegard and still used today, has asserted of her effect and permanence. The fact that Hildegard's idealization of God in nature of man and strongly underlines that God regards to man, distinguishes her from other mystics of the Middle Ages who accepted the human as evil-doer. Hildegard's remarkable aspects are that she voiced the need for reform within the class of priests and that women are closer to God than men who cannot protect God's trust. Hildegard permitted dressing, wearing jewelers, beautifying. These decisions have proved that she was outside general tendencies of her age. For example, Hildegard said that the nuns could dress white clothes like bridal gown unlike abbesses, who forced to wear a black hood. It can be said that Hildegard flexed hard lines of women for Paul and Augustine. But we think that she shares the traditional view on the sinfulness of Eve and supported that men are supremacy in sexual life, at home, in social life. For this reason, it is not possible to see Hildegard as a medieval feminist. This acceptance means falling into the danger of anachronism. In other words, it is possible to say that Hildegard did not show a radical break with the position of the woman in the tradition. It is said that she accepted the weakness of the woman who inherited from past, but she tried to get out of this negative heritage with the special gifts given to her by God.

Keywords: History of Religion, Christian Mysticism, Middle Age, Church, Hildegard.

\section{Kilise, Mistisizm ve Feodalite Perspektifinden Orta Çağlı Bir Hıristiyan Mistik: Bingenli Hildegard}

Öz

Hıristiyan mistisizmi Orta Çă̆'dan itibaren olgunlaşmaya başlamıştır. Bingenli Hildegard (1098-1179) Hıristiyan mistisizminin olgunlaşmaya başladığı bu dönemde dikkat çeken bir mistiktir. Kendisi Tanrı, insan ve âlem gibi konuları ele aldığı eserleri yanında müzik, botanik, anatomi gibi farklı disiplinlere ait düşünceleriyle de günümüze kadar etki etmiştir. Hildegard, gördüğü vizyonların da etkisiyle çevresindeki insanlar tarafından bir danışman veya gelecekten haber veren bir kâhin olarak kabul görmüştür. Bunun yanı sıra halka ve rahiplere vaaz vermek için farklı şehirleri dolaşmış, bu vaazlarda hem rahipler 
zümresini bazı hususlarda eleştirmiş hem de heretik akımlara karşı insanları uyarmıştır. Tanrı'nın bazı sıfatlarını feminen bir şekilde ele alması diğer yandan doğayı, Tanrı'nın sıfatlarını ve erdemleri birbirleriyle bağlantılı açıklaması Hildegard'1 farklı kılan özelliklerdir. Bu makalede Hıristiyan mistisizm tarihinin önemli bir halkasını teşkil eden Hildegard ve onun Hristiyan mistisizmine etkisi ele alınacaktır.

Anahtar Kelimeler: Dinler Tarihi, Hıristiyan Mistisizmi, Orta Çă̆, Kilise, Hildegard.

\section{Giriş}

Bingenli Hildegard, Orta Çağ'da yaşamış ve düşünceleri ile Hıristiyan mistisizmine etki etmiş bir mistiktir. Hildegard, hayatının çoğunu manastırlarda geçirmiş bir mistik olsa da bitkisel ilaç tedavileri, kilise müziklerini bestelemesi ve vaaz turlarına çıkan bir rahibe olmasıyla dikkat çekmektedir. Bu sayılan hususlardaki çalışmaları nedeniyle çok yönlü bir mistik olarak görülen Hildegard aynı zamanda ölümünden hemen sonra (1204) "Kilise Doktoru" unvan verilmesiyle de Hiristiyan mistisizm tarihinde önemli bir yer edinmiştir.

Hıristiyan mistisizmi ve Bingenli Hildegard çalışmaları Aydınlanma sonrası süreçte dini düşüncelere karşı başlayan eleştirilerden etkilenmiştir. Zira bu süreçte dinî düşünceler yanında mistik öğretiler de rasyonel bir değerlendirmeye tabi tutularak göz ard1 edilmeye başlanmıştır. Bu nedenle Hristiyan mistisizm tarihinin bir parçası olan Hildegard hakkında uzun bir süre akademik çalışma yapılmamıştır. Ancak XIX. yüzyıldan itibaren dinî ve mistik düşüncelerin öne çıkmasıyla beraber yeniden keşfedilen Hildegard, modern kadın hareketleri tarafından "Orta çağ idolü" olarak kabul görmüş ve hakkında yapılan çalışmalar artmaya başlamıştır. Her ne kadar feminist düşünürlerin Orta Çă̆'dan kendilerine lider arama girişimi bir anakronizm örneği olsa da bu çabanın Hildegard'ı yeniden öne çıkarttı̆̆ını söylemek mümkündür. Zira Batı'da 1970'li yıllara kadar Hildegard hakkında herhangi bir akademik teze rastlanmaz iken bu tarihten sonra çalışmaların arttığı ve 1990 yılından itibaren Hildegard'ın 
378 | H. TEMIZTÜRK / Kilise, Mistisizm ve Feodalite Perspektifinden Orta Çağlı Bir Hiristiyan Mistik: Bingenli Hildegard

çok sayıda teze konu olduğu bilinmektedir. ${ }^{1}$ Bu çalışmalarla beraber Hildegard "özgür kadının ideal modeli" ve "Rönesans'tan asırlar önce yaşayan Rönesans kadını" gibi sıfatlarla gazetelere konu olmuştur. Hildegard hakkında yakın dönemde yapılan bir film (Vision, y. 2009) yapılması, yaşadığı yerlerin bugün bir hac merkezi gibi kabul görmesi ve bestelediği müziklerin günümüzde kilise törenlerinde icra edilmesi onun Hıristiyanlıktaki etkinliğini göstermektedir.

Her ne kadar yapılan çalışmaların eksikliği nedeniyle azize ilan edilmesi mümkün olmasa da Kilise'nin verdiği "doktor" unvanı Hildegard'ın Katolik mezhebi için ne kadar önemli bir isim olduğunu göstermektedir. Zaman zaman karşı karşıya gelen Kilise kurumu ile mistikler düşünüldüğünde Hildegard ile Kilise arasında böyle bir çatışma yaşanmadığı görülmektedir. Hildegard kısmen Kilise yetkililerine karşı gelmiş olsa da asla Kilise'yi karşısına almamış, manastırı Kilise'nin alternatifi olarak görmemiştir. Ayrıca Hildegard'ın Kilise' nin Orta Çă̆' da baş etmekte zorlandığı başta Katarlar olmak üzere heretiklerle mücadelesinde aktif rol oynaması onun Kilise'nin desteğini aldığını göstermektedir. Tüm bunlara karşılık çıktığı vaaz turlarında rahipleri eleştirmesi ve Kilisedeki yolsuzlukları dile getirmesine papanın ve diğer yöneticilerin destek vermesi altında yatan sebepler neydi? Hildegard Kilise'nin sınırları içinde kalarak yani heretik olmadan Kilise kurumunu eleştirmeyi nasıl dengelemiştir? Ayrıca bir mistik olarak Ortaçağ'ın soyluluk, feodalite ve dinî anlayışını nasıl bir araya getirmiştir?

$\mathrm{Bu}$ sorulara cevap niteliğinde çalışmada Hildegard'ın yaşadığı çağın sosyal şartlarından bağımsız düşünceler geliştirmediği ve bu şartlara muhalif olacak şekilde yorumlayan bir mistik olmadığ vurgulanacaktır. Zira feodal bir toplum içerisinde büyümüş olan Hildegard, feodalitenin getirmiş olduğu tabakaları yadsımamış ve manastıra kabul edeceği rahibelerde soyluluk şartını aramıştır. Daha sonra soylu olmayan rahibeler için ayrı bir manastır inşa ettirmiş olsa da her iki grubun birbirine karışmamasına özen gösteren Hildegard kurt ve

1 Yurt dışı tezler hakkında bir kaynak olan Proquest verilerine göre, dini araştırmalar kapsamında Hildegard ile ilgili yapılan tezler ile ilgili için bk. Proquest, "ProQuest Dissertations \& Theses Global", erişim: 20.11.2017, https://search.proquest.com/pqdtglobal/results/25C6A43E3EA94D74PQ/1?accountid= 7412 . 
kuzuların bir arada olmaması örneği gibi benzetmelerle bunun Tanrı'nın bir emri olduğunu ifade etmiştir. Makalede vurgulanacak diğer bir husus da Hildegard'ın sıkı bir asketizm taraftarı olmadığı ve Aziz Benediktus gibi daha aktif bir manastır hayatı sürdürdügüüür. Böylece Hildegard'ın sadece manastır sınırları içinde kalan pasif bir münzevi olmadığı gösterilmeye çalışılacaktır.

Makale son yıllarda etkisi artan Hıristiyan mistisizminin önemli bir parçası olan Hildegard'ın Kilise ve soylular arasında kurduğu ilişki ve buna bağlı olarak gelişen mistik düşüncelerinin değerlendirilmesi üzerinde durmaktadır. Batı'da Hildegard çalışmaları son dönemde artmış olsa da ülkemizde Bingenli Hildegard'ın mistik düşünceleri ile ilgili herhangi bir yüksek lisans ve doktora tezine rastlanmamaktadır. Bingenli Hildegard'ın ele alındığı tek çalışma Haydar Akın'ın Ortaçă̆g'da Bilge Bir Kadın Bingenli Azize Hildegard ${ }^{2}$ adlı eseridir. Ancak söz konusu eser akademik bir çalışma olmayıp temelde Hildegard'ın hayatını aktarmaya odaklanan roman tarzında bir kaynak mahiyetindedir. Yazarın kendisi de eserinin giriş kısmında Hildegard'ın eserlerini yorumlama ve mistik çözümlemeler yapma niyetinde olmadığını, sadece onun hayatını sunmayı amaçladığını belirtmiştir. ${ }^{3}$

Makale, Kilise, mistisizm ve kadın hususları odağında tarihsel bir kesiti incelemektedir. Bu hususlar gündeme geldiğinde yapılan çalışmalar genelde sahip olunan bir düşüncenin doğrulanması şeklinde okunmaktadır. Bu yaklaşımdan uzak durmak için Hildegard'ın eserleri ve onun hakkında yazılan değerlendirmeler özümsenmiş, düşünceleri geniş bir kritiğe tabi tutularak değerlendirilmeye çalışılmıştır. Hildegard'a ilişkin bazı eserlerde onun "feminist bir Orta Çağ idolü" olarak nitelenmesine rağmen bu türden anakronik yaklaşımlardan ve popüler söylemlerden uzak durulmuş, olabildiğince nesnel bir yaklaşım takip edilmiştir. Bu açıdan Hildegard'ın hem kendi eserleri hem de Barbara Newman, Slabina Flanagan gibi Hildegard uzmanlarının yazdığ1 eserler incelenmiştir. Böylece Hildegard'in kadın konusundaki görüşlerine yer veren eserler sorgulayıcı bir bakış açısıyla çapraz

2 Haydar Akın, Ortaçă̆dan Bilge Bir Kadın Bingenli Azize Hildegard (İstanbul: Dharma Yayınları, 2005).

3 Akın, Ortaçağdan Bilge Bir Kadın Bingenli Azize Hildegard, 13. 
380 | H. TEMIZTÜRK / Kilise, Mistisizm ve Feodalite Perspektifinden Orta Çağlı Bir Hıristiyan Mistik: Bingenli Hildegard

okumaya tabi tutulmuştur. Ayrıca çalışmamız Orta Çă̆'1 ilgilendirdiğinden, bu dönemdeki Kilise ve mistikler arasındaki ilişkiyi doğru tanımlamak için farklı bakış açılarına odaklanan okumalar yapılmıştır. Bu doğrultuda Hıristiyan mistiklerin tamamen dünyadan feragat ettiğine dair genel kabullerin aksine bu dönemde manastırların siyasi, ekonomik ve toplumsal ilişkileri önemsediklerine dair bilgiler elde edilmiştir. Dolayısıyla mistikler ile Orta Çă̆'ın dinamikleri arasındaki ilişkiyi ortaya koymak için sözü edilen farklı görüşler geniş bir perspektiften ele alınmaya çalışılmıştır.

\section{Hildegard'ın Doğduğu Dönemin Dinî ve Siyasi Koşulları}

Hildegard, dinsel tartışmaların, sosyal ve ekonomik dönüşümlerin yaşandığı XI. ve XII. yüzyılın kesiştiği bir zaman diliminde (1098-1179) yaşamıştır. Hildegard'ın doğmuş olduğu Mainz bölgesi günümüzde Almanya sinırlarında kalsa da bölgenin tarihi Roma İmparatorluğu'na kadar uzanmaktadır. Bu bölge Alman ırkının ortaya çıkmasından çok daha önce Roma egemenliği altında olduğu için" Hildegard için "Alman mistiği" demek pek mümkün değildir.

Hildegard'ın doğduğu dönemde Kutsal Roma ve Alman İmparatoru sıfatıyla bilinen IV. Henry (Heinrich) başta bulunmaktaydı. $\mathrm{Bu}$ dönemde Henry ile dönemin Papası VII. Gregorius arasındaki mücadeleler kızışmış ve Alman prensleri Henry'e karşı isyan etmişti. ${ }^{5}$ Kral Henry bu isyancıları bastırmış, ardından kendi atamış olduğu papa tarafından imparator ilan edilmiştir. Sakinleşen bu geçici durum XII. yüzyılda yerini yeniden siyaset ve Kilise arasındaki anlaşmazlıklara bırakmıştır. ${ }^{6}$ Bu açıdan XII. yüzyıl Hildegard'ın da kısmen dahil olacağı, papalık seçimleri merkezinde yaşanan ayrılıkların, siyasal ve dinsel tartışmaların arttığı bir dönem olmuştur. Bu karışıklıkları tetikleyen imparatorlardan birisi de Hildegard'ın çağdaşı olan I. Friedrich'tir.7

4 Mary Fulbrook, Almanya'nın Kısa Tarihi, trc. Sabri Gürses, 2. Baskı (İstanbul: Boğaziçi Üniversitesi Yayınları, 2011), 23.

5 Muammer Gül, Orta Çă̆ Avrupa Tarihi (İstanbul: Bilge Kültür Sanat, 2009), 125.

6 Gül, Orta Çă̆ Avrupa Tarihi, 126.

71122 yılında Almanya'nın Waiblingen bölgesinde doğan Friedrich, sahip olduğu sakalları nedeniyle Barborossa (İtalyanca kızıl saç) lakabıyla tanınmıştır. 1152-1190 yılları arasında hükümdarlık yapan Friedrich kendi döneminde haçlı seferlerini 
Hildegard, Friedrich'in kral tayin edilmesinden sonra hem onu tebrik etmek hem de ayrılıkları sona erdirmesi umuduyla ona bir mektup yazmıştır. Friedrich'in cevabında Hildegard'dan dua istediği, onu kutsal bir kadın kabul ederek Ingelheim'de bulunan sarayına davet ettiği bilinmektedir. ${ }^{8} 1150$ 'li yılların ortalarında gerçekleştiği düşünülen bu buluşma hakkında fazla bilgi olmasa da Hildegard'ın bu süreçte Friedrich ile iyi ilişkiler içinde olduğu görülmektedir. Ancak 1159 yılında başlayan papalık seçimleri sürecinde Hildegard ile Friedrich karşı karşıya gelmişlerdir. Hildegard, Friedrich'in seçtiği papaların ayrılıkları körükleyeceğini düşündüğü için onu uyarmış ve Çıkış 22/24'de geçen "Yaşamak istiyorsan bana kulak ver. Yoksa kılıcım seni mahvedecek" cümlesini hatırlatarak Friedrich'i tehdit etmiştir. ${ }^{9}$ Aynı şekilde mektuplarında, Friedrich'i küçük bir çocuk ve deli olarak nitelemiş, gözlerinin körlüğü nedeniyle onun doğru işler yapamadığını ifade etmiştir. ${ }^{10}$

Ancak bu çekişmelere rağmen Friedrich'in 1163 yılında Aziz Rupert manastırına verdiği imparatorluk koruması dikkat çekmektedir. Bu noktada Friedrich'in Hildegard'ın kutsal bir kadın olduğunu kabullendiği, kendisine muhalefet etmesine rağmen ondan dua istediği böylece imparatorluk işlerinde başarılı olmayı arzuladığı düşünülebilir. Ancak kanaatimizce Friedrich bu korumayla beraber Hildegard'ın dile getirdiği eleştirilerin yeni bir din-siyaset kavgasına dönüşüp imparatorluğa zarar vermesini engellemek istemiştir. Zira aristokrat bir aileden gelen, dönemin piskopos, rahip ve mistikleri ile mektuplaşarak iletişim kuran, diğer yandan papa ile yakın ilişkiler içinde olan Hildegard'ın bu bağlantıları kullanarak yeni bir muhalefet oluşturması mümkündü. Hildegard ve Friedrich arasındaki bu mücadele 1122'ye kadar sürmüş Hildegard'ın ölümünden sonra bu mücadele papalık ile Alman soylularının büyük ölçüde zaferiyle sona ermiştir. Böylece Alman krallarının Kilise ve büyük Alman prensleri üstündeki yetkileri ciddi bir biçimde zayıflamış ve Almanya'da feodalleşme süreci hızlanmıştır.

organize etmesi, papalık seçimlerine müdahalesi ve ruhban sınıfına olan müdahaleleri ile etkin bir güç olmuştur.

8 Joseph Baird, The Personal Correspondence of Hildegard of Bingen-Selected Letters with an Introduction and Commentary (Oxford: Oxford Universty Press, 1994), 77.

9 Baird, The Personal Correspondence of Hildegard of Bingen, 77.

10 Baird, The Personal Correspondence of Hildegard of Bingen, 77. 
382 | H. TEMIZTÜRK / Kilise, Mistisizm ve Feodalite Perspektifinden Orta Çağlı Bir Hiristiyan Mistik: Bingenli Hildegard

Hildegard'ın Kilise içesindeki ayrılık tehlikesine yaptığ 1 vurguya rağmen onun ölümünden sonra bu muhtemel tehlikeler gerçeğe dönüşmüştür. Özellikle II. Friedrich'den sonra (ö. 1250) siyasi ve dinî kurumların üstünlük mücadelelerine sahne olan Büyük Fetret (1250-1273) dönemindeki bu anlaşmazlıklar dinî ve siyasi ayrılıkları arttırmıştır. ${ }^{11}$

Kaynaklara göre, Hildegard 1098 yılında Mainz piskoposluğuna ${ }^{12}$ bağlı Bermersheim ${ }^{13}$ olarak bilinen yerde (Ek-1) annesi Mechthild ve babası Hildebert'in onuncu çocuğu olarak doğmuştur. Bu bölgenin Benedikten ve Sisteryan gibi farklı kuralları takip eden manastırlarla çevrili bir yer olduğu bilinmektedir. ${ }^{14}$ Mainz arşiv kayıtlarına göre Hildebert ve eşinin ailelerinden tevarüs eden soyluluk nişanesine sahip oldukları aktarılmaktadır. ${ }^{15}$ Hildegard'ın doğduğu dönemde de devam eden bu soyluluk unvanı, hem aileye siyasi ve ekonomik bir güç katmış hem de Hildegard'ın manastırlara kabulündeki aranan soyluluk şartını sağlamıştır.

Hildegard ismi eski Almancada savaş anlamina gelen "hild" kelimesi ile, "kapatma", "çevrelemek" ve "korumak" anlamina gelen "gard" kelimesinin birleşiminden oluşmaktadır. ${ }^{16}$ Almanca kaynaklarda "Hildegarde" ve "Hildegard von Bingen" (Bingenli) şeklinde yer alan isim, eski Almanca kaynaklarda Hildegardis olarak geçmektedir. İsmi ile özdeşleşen "Bingen" ise Hildegard'ın doğduğu yere değil, hayatını uzun

11 Jacques Le Goff, Orta Çă̆ Batı Uygarlığı, trc. Hanife Güven - Uğur Güven (Ankara: Doğu Batı Yayınları, 2017), 103.

12 Mainz piskoposluğu Latince'de Moguntina olarak bilinir ve ilk piskoposluk merkezliğinin VIII. yüzyılda kurulduğu ve ilk piskoposluk görevinin de 745-754 yılları arasında Aziz Bonifas tarafından yapıldığı bilinmektedir. Kilise'nin bugünkü Almanya dediğimiz bölgeler III. Henry (d. 1017, ö. 1056) zamanında, içinde Hildegard'ın bulunduğu manastırların da bağlı olduğu Mainz gibi altı başpiskoposluk merkezine ayrılmıştır.

13 Günümüzde Almanya'nın batı tarafında kalan ve sınırları Ren nehri boyunca uzanan bir kasabadır.

14 Hugh Feiss, "Introduction", Hildegard of Bingen, Two Hagiographies: Vita Sancti Rupperti Confessoris and Vita Sancti Dysibodi Episcopi, ed. Christopher P. Evans - Hugh Feiss (Leuven: Peeters Publishers, 2010), 9.

15 Akın, Orta Çă̆dan Bilge Bir Kadın Bingenli Azize Hildegard, 18.

16 Behind the "Hildegard", erişim: 12.2017, http://www.behindthename.com/name/hildegard. 
süre sürdürdüğü Aziz Rupert manastırının kurulduğu Bingen bölgesine nispetle verilmiştir. Hakkında kaleme alınan yazılarda kullanılan diğer bir isim ise Ren Kâhini (Sybil of Rhine)'dir. Bu isim Hildegard'ın çocukluktan itibaren gördügü vizyonlara ve birtakım hastalıklara tedavi etmesi nedeniyle verilmiştir.

Hildegard daha çocukluk yıllarında ilginç ve tuhaf bazı deneyimler tecrübe etmeye başlamıştır. Beş yaşlarında henüz doğmamış bir buzağının rengini bilen Hildegard'ın bu yaşlardan itibaren çevresinde fark edilen birisi olduğu aktarılmaktadır. ${ }^{17}$ Hildegard'ın kendisi de bu dönemlerde parlak 1şıklar ve tuhaf vizyonlar gibi olağanüstü imgeler gördüğünü ancak bunları izah edemediğini söylemiştir. ${ }^{18}$ Hildegard, manastırdaki öğretmeni Jutta ile tanışıncaya kadar bu gördükleri hakkında uzun süre sessiz kalacaktır. Hildegard'in hayatı boyunca yaşamak zorunda kalacağı hastalıklar onu küçük yaşlardan itibaren etkilemiştir. Bu dönemde başlayan migren ağrıları zamanla hayatını zorlaştırmış ancak diğer taraftan Hildegard bu hastalığın Tanrı ile iletişimine vesile olduğuna inanmıştır. ${ }^{19}$

\section{Manastır Hayatı}

Dindar bir aileye sahip olan Hildegard, ailesinin Eski Ahit metinlerinde geçen "İster toprağın ürünü ister ă̆acın meyvesi olsun, toprakta yetişen her şeyin ondalığı Rab'be aittir. Rab için kutsaldır."20 emri gereği onuncu çocuk olduğundan bir şükür ifadesi olarak Tanrı yoluna adanmıştır. Tanrı yoluna adanacak bir hayat için en uygun mekân ise manastırdır. Hildegard'ın manastıra teslim edilme kararında ailesi kadar, ruhban sınıfından olan diğer aile üyeleri de etkin olmuştur. Çünkü ailesinin bu manastır kararını ruhban sınıfındaki aile dostlarına danışıp, onaylattıkları düşünülmektedir. ${ }^{21}$

17 Barbara Newman, Sister of Wisdom- St. Hildegard's Theology of the Feminine- (California: University of California Press, 1997), 8.

18 Hildegard, The Letters of Hildegard of Bingen, (İng.) trc. Joseph L. Baird - Radd K. Ehrman (Oxford: Oxford Universty Press, 1994), 1: 27.

19 Newman, "Vision and Validation", Church History 54/2 (1985): 167.

20 Levililer 27/30.

21 Akın, Orta Çă̆dan Bilge Bir Kadın Bingenli Azize Hildegard, 21. 
384 | H. TEMIZTÜ̈RK / Kilise, Mistisizm ve Feodalite Perspektifinden Orta Çağlı Bir Hiristiyan Mistik: Bingenli Hildegard

Hildegard'ın manastıra dahil olduğu yaş konusunda farklı fikirler olsa da genel olarak sekiz yaşında manastıra girdiği düşünülmektedir. ${ }^{22}$ Böylece yeni ailesi ve eğitim mekânı olan manastır onun mistik düşüncelerine, kilise ve siyaset ile olan münasebetlerine ev sahipliği yapacaktır. Aziz Disibod manastırı Hildegard'ın hayatında çok önemli bir dönüm noktasıdır. Zira bu manastır 8 yaşından öleceği 81 yaşına kadar geçireceği 73 yıllık mistik hayatın ilk basamağı olmuştur.

\subsection{Aziz Disibod Manastırı}

Hildegard'ın, ileride manevi lideri (magistra) olacak Jutta ve adı Jutta olan diğer bir kadın ile beraber 1112 yılının 1 Kasım Azizler gününde Aziz Disibod manastırına girdikleri nakledilmektedir. ${ }^{23}$ Üç rahibe adayı Aziz Benediktus kurallarına göre faaliyet gösteren Disibodenberg erkek manastırının bitişiğindeki rahibe manastırına (convent/nunnery) yerleşmiştir. Rahibelerin katılımı ile çifte manastır (double monastry) özelliğine kavuşan Aziz Disibod manastırının idaresi başrahipte bulunmakta kadınlar konventin manevi liderliğini (magistra) ve öğretici rolünü ise Sponheimli Jutta üstlenmiştir. ${ }^{24}$ Hildegard, kendi eğitimine büyük katkısı olan Jutta'nın 1136 yılında ölümü üzerine en güçlü aday olarak bu konventin başrahibesi olmuştur. Hildegard'ın 38 yaşında magistra olduğu sırada kadınlar konventinin on kişiye ulaştığı aktarılmaktadır. ${ }^{25}$

Hildegard başrahibe olmasının verdiği otorite ile çocukluğundan itibaren gördüğü vizyonları artık manastır dışına açmaya da karar vermiştir. Ancak Hildegard, vizyonları için göksel âlemden onay alsa bile dünyevi otoriterlerden onay almak zorunda olduğunun bilincinde idi. Özellikle yaşadığı dönemde kadının konumu gereği Kilise otoritelerinden bu onayı alması elzemdi. Bu açıdan Hildegard dikkatli bir politika izlemiştir. Öncelikle kendisinin şeytan tarafından aldatılan ya da gurur dolu bir kadın olmadığını göstererek geleneksel bakışın dışına çıkmadığını göstermeye çalışmıştır. ${ }^{26}$ Vizyonları için Kilise yetkililerine

22 Baird, "Introduction", 5.

23 Anna Silvas, Jutta and Hildegard: the Biographical Sources-Medieval Women: Texts and Contexts (Pennsylvania: Pennsylvania State Universty Press, 1999), 51.

24 Feiss, "Introduction", 11.

25 Feiss, "Introduction", 11.

26 Baird, "Reaching Out", The Personal Correspondence of Hildegard of Bingen, 17. 
gönderdiği mektupta "biçareden daha biçare olan kadın halimle, dilimin anlatamadı̆̆ oldum" ifadesi bu durumu açklamaktadır. ${ }^{27}$ Hildegard bu ifadeleri kullanarak aslında kendi yerini bildiğini ancak Tanrı'nın erkek rahipleri yetersiz gördüğünden bu mucizeleri bir kadına açtığını ifade etmeye çalışmıştır. Böylece kendisi için değil, Kilise'yi önemsediğinden bu vizyonları anlatmaya çalıştığını söyleyerek bunun bir Tanrı müdahalesi olduğunu ifade etmiştir. ${ }^{28}$

Hildegard vizyonlarının onayı için ilk adımı Clairvauxlu Bernard ile atmıştır. Aziz Bernard, Sisteryan tarikatına mensup olmasından dolayı papa ile yakın birisiydi. ${ }^{29}$ Hildegard 1146 yılında ona göndermiş olduğu mektupta kadınsı bir mahcubiyet ve tevazu içerisinde vizyonlarını anlatmış ve satır aralarında Bernard'a olan hayranlığını dile getirmiştir. ${ }^{30}$ Örneğin onu güneşe doğru korkusuz bir şekilde bakan bir adam olarak gördüğünü ve bu durumdan etkilenerek ağladığını ifade etmiştir. ${ }^{31}$ Hildegard, bu mektupla Tanrı'dan geldiğini söylediği vizyonlarını dış dünyaya taşımıştır. Bernard'ın cevaben gönderdiği mektup ise Hildegard'a göre oldukça sadedir. Ayrıca onun vizyonlar konusunda ihtiyatlı bir yaklaşım sergilediği görülmektedir. Bernard, Tanrı lütfuna eriştiğini söyleyen Hildegard'a hitaben "bizim sana tavsiye vereceğimiz ne olabilir ki?" diye hitabı dikkat çekicidir. ${ }^{32}$ Bernard, Tanrı'nın ona lütufkâr davranmasıyla mutlu olduklarını ve dua etmeye devam etmesi gerektiğini dile getirmiştir. ${ }^{33}$ Nihayetinde Hildegard, Bernard'in vizyonları soruşturacağını söylediği mektupla beklediği onayı kısmen almıştır. ${ }^{34} \mathrm{Bu}$ açıdan Hildegard için 1147-1148 yılları arasında yapılan Trier Sinod'u bir dönüm noktasıdır. Zira Jutta ve Volmar'a açtığı

27 Baird, The Personal Correspondence of Hildegard of Bingen, 18.

28 Dickens, The Female Mystic, 29.

29 Baird, "Introduction", The Personal Correspondence of Hildegard of Bingen, 16.

30 Mektupta Hildegard, Aziz Bernard'ın sadece kendisini değil, bütün insanlığını kurtaran bir kişi olduğunu adeta güneşe doğru uçan bir kartal gibi göründügünü dile getirmiştir. Baird, The Personal Correspondence of Hildegard of Bingen, 18-19.

31 Baird, The Personal Correspondence of Hildegard of Bingen, 19.

32 Baird, The Personal Correspondence of Hildegard of Bingen, 20.

33 Baird, The Personal Correspondence of Hildegard of Bingen, 21.

34 Baird, The Personal Correspondence of Hildegard of Bingen, 20-21. 
386 | H. TEMIZTÜRK / Kilise, Mistisizm ve Feodalite Perspektifinden Orta Çağlı Bir Hiristiyan Mistik: Bingenli Hildegard

vizyonlar Aziz Disibod manastırı başrahibi Kuno aracılığıyla Mainz piskoposu Heinrich'e ulaşmış o da bu sinodda mezkur vizyonlar hakkında bilgi vermiştir. ${ }^{35}$

Diğer taraftan Hildegard, Bernard'in hem arkadaşı hem de Sisteryan tarikatına bağlı olmakla yakınlığı bulunan Papa III. Eugene (Eugenos) ile mektuplaşmış ve o zaman yarısı yazılmış olan Scivias'ın onaylanma sürecini hızlandırmıştır. Papa'nın talimatları doğrultusunda vizyonların soruşturulması için iki delege Aziz Disibod'a gönderilmiştir. ${ }^{36}$ Nihayetinde soruşturma için gelen delegeler henüz tamamlanmamış Scivias adlı eseri teslim almıştır. Papa eseri önce kendisi okumuş ve ardından rahiplerin onayına sunmuştur. Newman, Aziz Bernard'ın Papa'ya ulaşan bu vizyonların kabulü noktasında rahipler kurulunu ikna ettiğini ileri sürer. ${ }^{37}$ Hildegard, böylece vizyonlarının kabulü ile artık kendini kabul ettirme probleminden kurtulmuştur. Hildegard'ın vizyonları için gerekli olan bu onayı alması adına bir taraftan Aziz Bernard'a diğer taraftan başpiskopos ve Papa ile iletişime geçmesi dikkatli ve sistemli bir strateji geliştirdiğini göstermektedir.

Hildegard, vizyonlarının Papa Eugenus'un katıldığı Trier sinodunda onaylanmasıyla daha da tanınır olmuştur. Böylece kaldığ Aziz Disibod, hacıların, rahibelerin dua istediği; hasta veya şeytana musallat olmuş olan kişilerinse şifa bulmak için geldiği bir manastır halini almıştır. Bu gelişmeler sonrasında rahibelerin sayısı artmıştır. Özellikle Hildegard'ın vizyonları sonrası manastırın tanınması ile rahibe olmak için başvuranların çoğalması onun sadece kadınlara ait bir manastır kurma ideallerini hızlandıracaktır. Ancak bu süreç çok da kolay olmamıştır. Hildegard'ı bu ayrılık konusunda düşündüren meselelerden birisi sadece kadınlara ait bir manastırın toprak, bina, yiyecek gibi ihtiyaçları için gerekli olan işgücü ve maddi kaynak teminidir. Zaten bu gibi ihtiyaçlardan dolayı genelde kadın rahibeler erkek manastırlarına yakın yerlerde olmaktaydi. Ancak kurulacak yeni manastır sadece kadınlara ait olacağı için bu eksiklikler problem teşkil edebilirdi. Hildegard bu problemlerin çözümü için dikkatli bir siyaset izlemiştir.

35 Newman, Sister of Wisdom, 8.

36 Newman, Sister of Wisdom, 8.

37 Newman, Sister of Wisdom, 8. 
Hildegard'ın öncelikle bu ayrılığa karşı gelen Baş rahip Kuno'yu ikna etmesi gerekmektedir. Başrahip Kuno kendi himayesindeki bu kadınlar konventinin ayrılmasına karşı çıkmıştır. Zira bu kararının arkasında rahibelerin manastıra gelişlerinde getirdikleri drahomalardan (çeyiz) mahrum kalma ve Hildegard'ın kazandığı şöhret ve getirilerinden faydalanamama gibi farklı sebepler vardır. ${ }^{38}$ Çünkü rahibe adaylarının yanlarında getirdikleri ve cemaate katıldıktan sonra da ailelerinden gelmeye devam eden maddi katkılar manastırlar için önemli bir gelir kaynağıdır. Hildegard'ın vizyonlarının Papa tarafından kabulü sonrası manastıra başvuran rahibelerin artması ile manastır ihtiyaçlarını karşılamayı bekleyen Aziz Disibod idaresi haliyle bu karara soğuk bakmıştır. ${ }^{39}$ Başrahip Kuno bu ayrılışı çocukluğundan beri himaye ettikleri bir kadının, kendi liderine yüz çevirmesi ve kadınlara ait bir manastır kurma fikri ile Tanrı'nın erkek öncülüğünde kurduğu hiyerarşiye karşı gelmesi olarak görmekteydi. ${ }^{40} \mathrm{Bu}$ süreçte oldukça yıpranan Hildegard'ın sağlığ 1 da kötüye gitmiştir. Nihayetinde Mainz başpiskoposu Heinrich, rahibe Richardis' in annesi Kontes Magravine, Richardis'in kardeşi Bremen başpiskoposu Hartwig' in destekleri ile Kuno istemeyerek de olsa bu ayrılığa onay vermiştir. Bu destek Hildegard'ın manastır sınırlarında kalan, dış dünya ile bağlantıları koparan katı bir asketizm taraftarı olmadığını göstermektedir.

\subsection{Aziz Rupert Manastırı}

Aziz Disibod manastırının son dönemlerinde yaşadığ 1 olumsuzluklarla taşınma süreci yavaşlamış olsa da Hildegard nihayetinde, 1150 yılında 18 rahibe ile yeni manastıra doğru hareket etmiştir. ${ }^{41}$ Yeni manastırın arazisinin temin edilmesinde Hildegard'ın manastıra taşındığı sırada yanında olan ve sonraki dönemlerde de yakın arkadaşı olacak olan Richardis' in ailesi etkili olmuştur. ${ }^{42}$ Soylu ve maddi olarak güçlü bir aileye sahip olan Richardis'in annesi Margravine'nin manastırın arazisi ve gerekli masraflar konusunda onlara yardımcı olduğu bilinmektedir. Ayrıca İmparator Friedrich Barborossa'nın üvey

\footnotetext{
38 Feiss, "Introduction", 12.

39 Baird, The Personal Correspondence of Hildegard of Bingen, 29.

40 Baird, The Personal Correspondence of Hildegard of Bingen, 29.

41 Newman, Sister of Wisdom, 9.

42 Flanagan, Secret of God-Writings of Hildegard of Bingen-, 160.
} 
388 | H. TEMIZTÜRK / Kilise, Mistisizm ve Feodalite Perspektifinden Orta Çağlı Bir Hıristiyan Mistik: Bingenli Hildegard

kardeşi Pfalz Kontu Konrad ve Kral III. Konrad'ın kız kardeşi Stahleckli Bertha gibi imtiyazlı kişiler de bu süreçte Hildegard'a destek vermişlerdir. ${ }^{43} \mathrm{Bu}$ dönem Hildegard'ın "Bingenli Hildegard" olarak tanınmasını sağlayan bir zaman dilimidir. Çünkü Hildegard'ın kurduğu Aziz Rupert manastırı, Nahe ve Ren nehirlerinin birleştiği bu "Bingen" adlı bölgede yer almaktadır. ${ }^{44}$ Yeni bir manastırın sıkıntıları ile yüzleşen Hildegard bir taraftan manastırdaki kadınların eğitimi ile ilgilenirken diğer taraftan manastırın Kilise otoritelerince tanınması için çalışmıştır. Aziz Rupert vitasında Hildegard, yeni taşındıkları ve henüz resmen onaylanmamış manastırlarının resmi anlamda kabul görmesi ve tanınması adına eserlerini yazdı ̆̆ını belirtmiştir. ${ }^{45} \mathrm{Bu}$ açıdan yazdığı eserlerin bir amacı da manastırın otorite kazanmasına yöneliktir. Vizyonları ve yazdığı eserleri birçok kişi tarafından duyulan Hildegard'ın adı giderek yayılmıştır.

Hildegard, bir süre sonra Aziz Rupert manastırının karşısında yer alan Eibingen manastırını da (Ek-1) satın alarak tamir ettirmiş ve faaliyete geçirmiştir. Burası 1148 Agustinusçu rahipler tarafından kurulan ama 1165'de Friedrich Barborossa'nın askerleri tarafından yıkılan bir manastırdır. ${ }^{46}$ Bu manastırı soylu ailelerden gelmeyen kadınlar için tahsis eden Hildegard haftada bir kez burayı ziyaret etmiştir. ${ }^{47}$ Eibingen manastırı günümüze kadar gelmiş, Rupertsberg manastırı ise otuz yıl savaşları sırasında yıkılmıştır. ${ }^{48}$

\section{Halkı Uyarmak, Rahipleri Değiştirmek: Vaaz Turları}

1151 yılından ölümüne kadar olan süreç Hildegard'ın en etkin olduğu dönemdir. Zira bu tarihte en bilinen eseri Scivias'1 tamamlamış olan Hildegard, artık vizyon sahibi bir mistik kadın ve kâhin olarak kabul edilmeye başlanmıştır. Bu dönemde Hildegard kazandığı otorite ile çıkmış olduğu vaaz turlarında hem rahipler zümresine hem de halka hitap etme fırsatı bulmuştur. 1158 ve 1161 yılları arasında ilerlemiş hastalığına rağmen dört ayrı vaaz turuna çıkan Hildegard, bunların

\footnotetext{
43 Akın, Orta Çă̆dan Bilge Bir Kadın Bingenli Azize Hildegard, 97.

44 Baird, "Introduction", 8.

45 Feiss, "Introduction", 17.

46 Feiss, "Introduction", 15.

47 Feiss, "Introduction", 16; Newman, Sister of Wisdom, 10.

48 Newman, Sister of Wisdom, 10.
} 
ilkinde Mainz, Wertheim, Wiirzburg, Kitzingen, Ebrach ve Bamberg gibi şehirleri dolaşarak (bk. Ek-2) manastır ve rahipler sınıfının reforma tabi tutulması üzerine konuşmalar yapmıştır. ${ }^{49}$ İkinci vaaz turunda güney bölgelerde bulunan Lorraine, Metz ve Krauftal'u gezen Hildegard ayrica Trier'de halka açık konuşma fırsatı bulmuştur. Üçüncü vaaz turunu 1161 ve 1163 yılları arasında Ren nehrinin aşağı kesimlerinde bulunan Boppard, Andernach, Siegburg, Köln ve Werden şehirlerine gerçekleştirmiştir. Hildegard, artık hastalığın iyice ilerlediği ve altmış yaşına geldiği bu dönemde dördüncü ve son vaaz turunu ise Swabia, Rodenkirchen, Maulbronn, Hirsau, Krchheim ve Zwiefalten şehirlerinde gerçekleştirmiştir. ${ }^{50}$

Hildegard bu vaaz turlarında Kilise içindeki ayrılıklara ve diş tehlikelere karşı Kilise'yi savunan bir politika izlemiştir. Hildegard'ın yaşadığ 1 dönemde Kilise'nin mücadele ettiği akımların başında Katharlar gelmektedir. Katharlar Kilise'nin önem verdiği haç sembolünün İsa için bir zulüm olduğunu düşünmekte, ayrıca ekmek şarap ayinini sembolik olarak kabul etmekte ve evliliğe karşı durmakta, kadın ve erkekleri tamamen eşit görmekteydiler.51 Katharlar Kilise'yi iki yüzlülükle suçlamakta, tüm 1srarlara rağmen faaliyetlerini durdurmamakta ve işkencelere aldırış etmemekteydiler. Katharlar'ın özellikle Hildegard'ın yaşadığ 1 Ren bölgesinde etkili oldukları bilinmektedir. ${ }^{52} \mathrm{Bu}$ doğrultuda Aziz Bernard ve Papa III. Eugenius'un Katharlar'a karşı göstermiş olduğu mücadeleye Hildegard'ın da katıldığı bilinmektedir. Hildegard 1160 yıllarında gittikçe faaliyetlerini artıran Kathar tehlikesine eserlerinde sık sık yer vermiştir. Çıktığı vaaz turlarında da rahipleri ve halkı Kathar tehlikesine karşı uyarmıştır. Hildegard Katharlar'ın artışının şeytanın dipsiz kuyularından çıkması olarak algılamış ve onların getireceği yıkım için Kilise'yi uyarmıştır. ${ }^{53}$ Hildegard Katharlar dışında isim vermeden diğer heretiklerin de Kilise'yi hedef alan faaliyetlerinden özellikle Scivias adlı eserinde bahsetmiştir.

\footnotetext{
49 Newman, Sister of Wisdom, 11.

50 Newman, Sister of Wisdom, 12.

51 Sean Martin, the Cathars (New York: Thunder's Mouth Press, 2005), 43.

52 Martin, the Cathars, 43.

53 Martin, the Cathars, 51.
} 
390 | H. TEMIZTÜRK / Kilise, Mistisizm ve Feodalite Perspektifinden Orta Çağlı Bir Hiristiyan Mistik: Bingenli Hildegard

Hildegard'ın vaaz turlarında üzerinde durduğu diğer bir mesele de rahipler zümresinin içinde bulunduğu tembellik, ahlaki zaaflar ve dinî emirlerden uzaklaşması tehlikesidir. Bu vaaz turları arasında 1161 ve 1163 yıları arasında yaptığı üçüncü vaaz turu diğerlerine göre daha dikkat çekicidir. Zira Hildegard bu ziyaretler sırasında Cologne katedralinde (Köln) rahipler zümresi hakkındaki reform düşüncelerini bizzat rahip ve keşişlere hitap ederek açıklamıştır. Hildegard bu vaaz turlarında etkili bir hitabet kullanarak kendisini dinletmiştir. Altmış yaşlarında bir kadının erkek rahipler önündeki hitabı ve onları yaptıkları hatalar yüzünden azarlaması Orta Çağ'ın dinamikleri açısından sıra dışı kabul edilmektedir. ${ }^{54}$ Zira Hıristiyanlık tarihinde kadınların halka açık vaaz vermesi nadiren görülen bir durumdur. Eski Ahitte kadın peygamberlerin vaazlar yaptığı görülse de Pavlus'un mektuplarında bu yasaklanmıştır: "Kadınlar toplantılarınızda sessiz kalsın. Konuşmalarına izin yoktur. Kutsal Yasa'nın da belirttiği gibi, uysal olsunlar. Öğrenmek istedikleri bir şey varsa, evde kocalarına sorsunlar. Çünkü kadının toplantı sırasında konuşması ayıptır." ${ }^{55}$ Pavlus'un bu yasağının etkisi uzun süre devam etmiş ve Orta Çăg'a kadar kadınların vaaz vermesi pek görülmemiştir. Ancak $X$. ve XI. yüzyıllardan itibaren kadınların dinî hayattaki etkinliği artmış bu doğrultuda bazı kurallar çerçevesinde kadınlara vaaz verme hakkı da verilmiştir. ${ }^{56} \mathrm{Bu}$ açıdan Hildegard'ın kadınlara verilen bu kısmi vaaz izninden yararlandığı daha doğru bir çıkarımdır. XII. yüzyılda belirli şartlar altında kadınların kilise işleri ile ilgili konuşmasına ve dinî sorulara cevap vermesine izin verilse de, 1230 yilından sonra soru sorma hakkının sadece ruhani statüde olanlara verildiği bilinmektedir. ${ }^{57}$ Zaten Thomas Aqunias gibi düşünürlerin ilahi mesaja muhatap olsa bile kadınların halka açı vaaz vermemesi gerektiği düşüncesi Hildegard sonrası dönemde kadınlar için bu vaaz verme yasağının yeniden $X$. yüzyıl

54 Baird, The Personal Correspondence of Hildegard of Bingen, 123.

55 I. Korintililer 14/34-35.

56 Özlem Genç, “Orta Çağ Avrupasında Kadın”, Orta Çă̆'da Kadın, ed. Altan Çetin (Ankara: Lotus Yayınevi, 2011), 265.

57 Genç, “Orta Çă̆ Avrupasında Kadın”, 266. 
öncesine döndüğünü göstermektedir. ${ }^{58}$ Dolayısıyla Hildegard'ın kendinden sonra yaşayan Magdeburglu Mechilth (1207- ö. ?), Norviçli Julian (1342-?) gibi mistik kadınlara nazaran daha müsamahalı bir dönemde yaşadığı söylenebilir.

Hildegard bu süreçte bir taraftan eser ve vaazlarıyla insanları uyarmaya çalışırken diğer taraftan papalık seçimlerine müdahil olmuştur. Hildegard parçalanmaya doğru giden Kilise'nin toparlanması için papanın önemli bir güç olduğunu düşünmüş ve bunun için siyasi otorite ile zaman zaman karşı karşıya gelmiştir. 1150 yılından sonraki otuz yıl boyunca Kilise politikalarına müdahale eden Hildegard, Barbarossa'nın tartışmalı isimler olan dört farklı papayı ataması ile ayrılıkları körüklemesine mektupları ile karşı gelmiştir. ${ }^{59}$ Örneğin Hildegard göreve daha layık olduğunu düşündüğü Alexander yerine IV. Victor'un atanmasını doğru bulmamıştır. Victor'un 1164 ölümü ile İmparator Barbarossa'nın bir başka tartışmalı isim olan Pascal'ı atması Hildegard'ın ikinci kez imparatoru eleştirmesine neden olmuştur. Hildegard imparatora gönderdiği mektupta onu "çılgın", çocuk" gibi sıfatlarla azarlamıştır. ${ }^{60}$ Ancak Barborossa buna rağmen Pascal'ın 1168 ölümü ile birlikte yine Hildegard'ın istemediği Calixtus'u atamıştır. Hildegard yazdığı mektupta bu sefer kralı tehdit edercesine ona şöyle seslenmiştir: "Tanr şöyle der: Asiliği yok edeceğim ve beni önemsemeyeni ezip geçeceğim. Bana meydan okuyan o zavallı adama yazıklar olsun! Ey Kral eğer yaşamak istiyorsan dinle dediklerimi yoksa kllıcım seni tarumar edecek." 61

Hildegard, İmparator Friedrich ile inişli çıkışlı bir ilişki içinde olmuştur. Daha önce sözü geçtiği gibi Friedrich bir taraftan Hildegard'1 sarayına davet ederek ona yakınlık göstermiş ve ondan tavsiye almış ancak diğer taraftan papalık seçimlerinde ona karşı gelmiştir. Daha da dikkat çeken diğer bir olay da Friedrich'in Aziz Rupert manastırı için imparatorluk koruması vermesidir. 1163 yılında yapılan Ingelheim sarayı

58 Alastair Minnis, "Religious Roles: Public And Private", Medieval Holy Women in the Christian Tradition c. 1100-c. 1500, ed. Alastair Minnis - Rosalynn Voaden (Belgium: Brepols Publishers n.v., 2010), 48.

59 Andrea Janelle Dickens, The Female Mystic-Great Women Thinkers of The Middle Ages(London: I. B. Tauris \& Co Ltd, 2009), 28.

60 Baird, The Personal Correspondence of Hildegard of Bingen, 78.

61 Baird, The Personal Correspondence of Hildegard of Bingen, 78. 
392 | H. TEMIZTÜRK / Kilise, Mistisizm ve Feodalite Perspektifinden Orta Çağlı Bir Hıristiyan Mistik: Bingenli Hildegard

toplantısından birkaç yıl sonra verilen bu koruma ile Rupertsberg manastırındaki rahibeler ve manastır eşyaları imparatorluk muhafazasına alınmıştır. ${ }^{2}$ Daha sonra Friedrich'in papalık seçimleri konusundaki tavrı Hildegard'ın bu koruma kararına rağmen ona karşı gelmesini engelleyememiştir. Hildegard'ın bütün uyarılarına rağmen imparator kararlarından vazgeçmemiş ve büyüyen ayrılıklar 1177'ye kadar nihayete ermemiştir. ${ }^{63}$

\section{Soyluluğun Vermiş Olduğu Yetkinlikler}

1150 yılından itibaren Hildegard'ın sağlık problemlerinin artması ve hayatına tesir etmiş kişileri kaybetmesi sıkıntılı bir dönem geçirmesine sebep olmuştur. Aziz Disibod manastırında iken ölen Jutta'nın ardından Aziz Rupert manastırı döneminde yardımcısı olan Richardis ve sekreteri Volmar'ın ölümleri onu yıpratmıştır.

Richardis, 1151 yılında Bassum adlı bölgedeki manastıra başrahibe olarak görevlendirilmiş ve Hildegard'ın yanından ayrılmıştır. Hildegard bu ayrılığa engel olmaya çalışsa da nihayetinde Richardis annesinin soyluluğun getirmiş olduğu daha üst bir rütbe talep etmesi nedeniyle yeni görev yerine gitmiş ancak bir müdddet sonra ölmüştür. ${ }^{64}$ Hildegard'ın etkilendiği diğer olay ise sekreteri olan Volmar'ın 1173 yılındaki ölümüdür. Volmar, Hildegard'a sekreter, arkadaş ve sırdaş olarak yardım etmiş, manevi annesi olarak kabul ettiği Jutta kadar onun hayatına etki etmiştir. ${ }^{65}$ Hildegard Volmar'ı güvenilir bir keşiş olarak tanımlamakta ve onu vizyonları ile ilgili sırlarını açıklayacak kadar yakın görmektedir.

Volmar'ın ölümü üzerine yerine geçecek yeni sekreterin Aziz Disibod manastırı idaresi tarafından uzun süre atanmaması Hildegard' 1 bir kat daha üzmüştür. Manastırlara yönetici atama çoğunlukla kurucuları veya mirasçıları tarafından yapılmakta ya da Karolenj dönemine benzer şekilde belirli bir merkezden atanmaktayd1. ${ }^{66}$ Hildegard'ın yaşadığı bölgede ise yönetici atamaları piskoposluk ya da büyük manastırlar tarafından yapılmaktaydı. Bu açıdan Aziz Disibod

62 Newman, Sister of Wisdom, 12.

63 Newman, Sister of Wisdom, 13.

64 Baird, "Richardis von State", The Personal Correspondence of Hildegard of Bingen, 39.

65 Newman, Sister of Wisdom, 5.

66 Gül, Orta Çă̆ Avrupa Tarihi, 106. 
manastırından ayrılmış olan Hildegard bu olayla tekrar eski manastırın yöneticilerine muhtaç durumda kalmıştır. Bir süre sekreter talebi yerine getirilmeyen Hildegard durumu Papa Alexander'e iletmiş daha sonra Hildegard'ın hayatını yazacak olan Gottfried sekreter olarak atanmıştır. ${ }^{67}$ Papa'nın bu yardımı Hildegard'ın Kilise tarafından ne kadar önemsendiğini göstermektedir. Aynı zamanda bu durum Hildegard'ın dünyevî güçleri yeri geldiğinde kullandığına güzel bir örnektir.

Hildegard'ın hayatını derinden etkileyen diğer bir olay ise, 1178 yılında ölen bir gencin manastır bahçesine gömülmesidir. Aforoz edilen soylu bir genç olan bu kişinin Rupertsberg manastırının avlusuna gömülmesi Hildegard'ın, Kilise'ye karşı gelmiş günahkâr birisine yardım etmekle itham edilmesine neden olmuştur. Mainz Katedrali kuralları gereği gencin gömüldüğü yerden çıkarılması talebine karşın Hildegard bu karara karşı gelmiş bunun üzerine kilise yetkilileri manastıra interdict cezasını vermiştir. ${ }^{68} \mathrm{Bu}$ ceza Benediktenlerde oldukça faal olan liturjik törenlerin yasaklanması, sakramentlerin uygulanmaması ve manastır üyelerinin bu durumda ölmeleri halinde günahkâr olacakları anlamına gelmekteydi. Manastır için oldukça ağır olan bu kurallara rağmen Hildegard ölen birisinin mezarından çıkarılmasını uygun görmemiştir. Nihayetinde Köln başpiskoposu Philip, Hildegard ile Kilise arasında arabulucuk yapmış ve olayın soruşturulmasını talep etmiştir. Bunun üzerine gencin ölmeden önce vaftiz olduğuna dair tanık ve kanıtlar bulunmuştur. ${ }^{69}$ Bunun üzerine Başpiskopos Christian inderdict cezasını kaldırmıştır. Ancak Hildegard muhalifleri, Roma'daki III. Lateran Konsiline katılan Papa Christian'ı ikna ederek bu cezanın bir süre daha aktif olmasını sağlamışlardır. ${ }^{70} \mathrm{Bu}$ ceza 1179 yılının mart ayında yani diğer bir ifadeyle Hildegard'ın ölümünden altı ay önceye kadar uygulanmaya devam etmiştir.

Hildegard'ın çocukluğundan itibaren maruz kaldığ 1 hastalıklar, yeni manastıra taşınma süreci ile vizyonlarının kabulü sırasında yaşadıklarının üzerine bir de bu manastır bahçesine gömülen gençten

67 Newman, Sister of Wisdom, 14.

68 Dickens, The Female Mystic, 28.

69 Newman, Sister of Wisdom, 14.

70 Newman, Sister of Wisdom, 14. 
394 | H. TEMIZTÜRK / Kilise, Mistisizm ve Feodalite Perspektifinden Orta Çağlı Bir Hıristiyan Mistik: Bingenli Hildegard

dolayı aldığı cezalarla sağlığı giderek bozulmuş ve 17 Eylül 1179 tarihinde Bingen' de ölmüştür.

\section{Hildegard'ın Hıristiyan Geleneğine Katkısı}

Hildegard hem eserleriyle hem de yaşadığ 1 dönemdeki etkinliğiyle Hıristiyanlık tarihine ve mistik Hıristiyan literatürüne katkılarda bulunmuştur. Hildegard'ın erkek manastırından bağımsız bir hayatı seçmesi, rahibeler konvetinin magistrası olması, vaaz turları ile halka ve rahiplere hitabı, kilise müzikleri ve tıbbi bilgilere dair kitaplar yazması, eserlerini resimlerle zenginleştirmesi onun erken Rönesans'ının temsilcisi şeklinde yorumlanmasina sebep olmuştur. ${ }^{71}$

Hildegard, ölümünden kısa bir süre sonra azizelik süreci başlatılan ender kadınlardan birisidir. Ancak 1233' de Papa IX. Gregorius tarafından başlatılan azizelik sürecinin, Hildegard'ın hayatını ve vizyonlarını teftiş eden soruşturma ekibinin üstün körü yaptığ 1 çalışmalar ve isim, tarih ve yerler ile ilgili eksikliklerden dolayı tamamlanamadığı bilinmektedir. ${ }^{72}$ Sponheimli Trithemius'e göre bir diğer soruşturma 1243 ve 1317 arasında yapılmış ancak bu dönemde de yeterince tanığın kalmamış olması Hildegard'ın günümüze kadar azize ilan edilememesine neden olmuştur. ${ }^{73}$ Ancak buna rağmen Hildegard kültü hep canlı kalmış ve 1940 'dan itibaren Almanya'da daha canlı bir şekilde kendini göstermektedir. Ölüm tarihi olan 17 Eylül'deki anma etkinlikleri ${ }^{74}$ yanında ölümünün 800. yılı anısına Almanya posta teşkilatı tarafından pullar basılmış, 900. yılında ise uluslararası bir sempozyum düzenlenmiştir. Günümüzde Hildegard'ın yaşadığ1 Bingen bölgesi ise UNESCO tarafından Dünya Kültür Listesine alınmış ve çeşitli organizasyonlarca bu bölgeler Hıristiyanlar tarafından adeta bir hac ve ruhsal yolculuk merkezi olarak kabul görmektedir. ${ }^{75}$

71 Dickens, The Female Mystic, 29.

72 Newman, Sister of Wisdom, 15.

73 Newman, Sister of Wisdom, 15.

74 Newman, Sister of Wisdom, 15.

75 Abbey of Arts, "Hildegard of Bingen and the Greening Power of God: A Pilgrimage in Germany", erişim: 01.03.2018, https://abbeyofthearts.com/programs/live-classes-andretreats/hildegardpilgrimage/; Spritual Travels, "The Hildegard of Bingen Trail in Germany", erişim: 01.03.2018, https://www.spiritualtravels.info/articles-2/europe2/the-hildegard-of-bingen-trail-in germany/. 


\section{1. Çok Yönlü bir Mistik}

Hildegard'ın başta teoloji, mistisizm, olmak üzere bitkisel ilaçlar, müzik, doğa felsefesi farklı alanlara ait çok sayıda eseri günümüze kadar gelmeyi başarmıştır. Bu eserler arasında yer alan Scivias, Book of Life's Rewards, Book of Divine Works adlı kitaplar mistik ve teolojik üçleme (triloji) olarak tanınmakta ve Hildegard'ın en bilinen eserlerini oluşturmaktadır. Ayrıca bitkisel ilaç kürlerinin ağırlıkta olduğu Natural History veya Book of Simple Medicine ile fizik, medikal, kozmoloji ve kozmografi yanında 200 üzerinde hastalığın tanımı, sebepleri ve tedavi yöntenime değindiği the Causes and Cures veya Book of Compand Medicine adlı eseri dikkat çekicidir. Diğer taraftan Hildegard'ın günümüzde Kilise müzikleri olarak kullanılan liturjik şiir ve ezgilerden oluşan Symphony of the Harmony of Celestial Revelations adlı eseri önemlidir.

Hildegard'ın eserleri arasında kaldığı manastırların tarihi kadar kendi yaşamına da ışık tutan vitalar (yaşam öyküsü) vardır. Bunlardan biri 1150 civarında yazılmış olan Aziz Rupert, diğeri ise bundan yirmi yıl sonra yazılan Aziz Disibod'un vitasıdır. Hildegard'ın ötü ile erdem arasında ilişkiyi (psikomasi) anlattığı diğer bir eseri olan Order of Virtues (Ordo virtutem) ilk müzikli drama olması sebebiyle dikkat çekmektedir. Ayrıca Hildegard, Lingua İgnota veya Litterae İgnotae (Bilinmeyen Dil) olarak bilinen ve teoloji ve erdemlerden bahseden bir eser yazmıştır. Bu eser 900 yapay isimden ve eserin sonunda bu kelimelerin Almanca karşılıklarının bulunduğu sözlükten oluşmaktadır.

Hildegard'ın bunların yanında farklı konularla ilgili küçük çaplı çalışmalara da imza atmıştır. Bunlar arasında fizik hakkında uzun değerlendirmelerde bulunduğu Physica, kendisinin de tabi olduğu manastır kurallarını anlattığı Benedictine Rule, inanç ilkelerini savunan bir yapısı olan Athanasian Creed ve Guibert ve keşiş Villers'in otuz sekiz sorusuna verdiği cevaplardan oluşan Solitiones Triginta Octo Quaestionum eserleri sayılabilir. Bunların dişında papadan imparatora kadar önemli kişilerin aralarında bulunduğu kişilerle yazışmalarından oluşan 400'e yakın soru ve cevaptan oluşan mektuplar, Hildegard'ın günümüze kadar ulaşan eserleri arasındadır. ${ }^{76}$

76 Eserlerin el yazmaları farklı kütüphanelerde bulunmaktadır. Birçoğu Almanya'nın farklı şehirlerinde ve Avusturya'nın Viyana şehrinde yer almaktadır. El yazmaların 
396 | H. TEMIZTÜRK / Kilise, Mistisizm ve Feodalite Perspektifinden Orta Çağlı Bir Hıristiyan Mistik: Bingenli Hildegard

\subsection{Yaşadığ}

Hildegard, manastır hayatı merkezinde göstermiş olduğu dinî, siyasi ve sosyal içerikli düşünceleriyle yaşadığı döneme etki etmiş bir mistiktir. Hildegard'ın çağdaşı olan mistiklerden farklı bir duruş sergilediği ve bazı hususlarla daha öne çıtığını söylemek mümkündür. Bu hususlardan birisi Hildegard'ın Tanrı'nın varlığını insanda idealize etmesi ve Tanrı'nın insana verdiği değerin altını güçlü bir şekilde çizmiş olmasıdır. $\mathrm{O}$, bu yönüyle Orta Çağ'ın günah ile özdeşleşmiş insan anlayışına sahip diğer mistiklerinden ayrılmaktadır. ${ }^{77}$ Ayrıca rahipler sınıfı içerisindeki reform ihtiyacını sesli dile getirmesi ve Tanrı'nın emanetini koruyamayan erkeklere karşı kadınların emaneti aldığını dile getirmesiyle de dikkat çekmektedir. Diğer taraftan Geç Orta Çağ' 1 n birçok mistiğine nazaran Hildegard'ın sadece Tanrı ile olan mistik tecrübe üzerinde durmayıp, inanç ve ahlaki öğretilerden bahsetmesi de onu farklı kılmaktadır. ${ }^{78}$ Onun çağdaşları ile olan farklılı̆̆ını şu şekilde özetlemek mümkündür: "Hildegard'ın Latincesi diğger Sisteryan çağdaşlarından daha az etkili, odak noktası Kilise merkezi, vizyonları tarihsel olmaktan öte ilahi tasarrufa yönelik, dindarlı̆̆ı ise daha az bireysel ama daha să̆lamdır."79

Hildegard'ın dikkat çeken bir yönü de özellikle vizyonlarının onaylanmasından sonra kazandığı otoriteyi oldukça isabetli kullanmasıdır. O, vizyonlarında Tanrı adına birinci tekil şahıs kipi ile konuşmuş ve eserlerinde bu otoritesini güçlü bir şekilde kurmuştur. Bu otoritesi üzerine eklemlenen şifacı karakteri, Kilise ilkelerini savunması ve diğer mistiklere yol göstermesi gibi faktörler Hildegard'1 daha da ön plana çıkarmıştır. Ayrıca Richardis'in manastırdan ayrılmasına karşı çıkmasındaki haklılığının onun ölümüyle ortaya çıkması, papalık seçimlerinin ayrılık getireceğini önceden görmesi, heretik tehlikesini önceden sezip Kilise'yi uyarması gibi öngörülerinin daha sonradan gerçekleşmesi ona duyulan saygının artmasına sebep olmuştur. $\mathrm{Bu}$

bütün nüshaları için bk. Beverly M. Kienzle, "Introduction". A Companion to Hildegard of Bingen (Brill's Companions to the Christian Tradition- Book 45), ed. Debra Stoudt v.dğr. (Leiden, Boston: Brill, 2014), 323, 324.

77 Akın, Orta Çă̆dan Bilge Bir Kadın Bingenli Azize Hildegard, 90.

78 Newman, "Vision and Validation", 163.

79 Coroline Walker Bynum, "Preface", Scivias, 5. 
nedenle kendisine verilen isimlerden birisinin de Sybil (kâhin) olması dikkat çekicidir.

Günahlarından arınmak, cinlerden korunmak, politik güç elde etmek hatta sevdiği kişiye kavuşmak isteyenlerin tavsiye aradığı bir kişi olmuştur. ${ }^{80}$ Hildegard sadece hastaların veya gelecekten haber almak isteyenlerin değil aynı zamanda rahipler, kadınlar ve mistikler gibi toplumun farklı katmanlarından insanlar için de bir rehber olarak kabul görmüştür. Hildegard'a gelen mektuplarda onun birçok kadına ve rahibeye mistik danışmanlık hizmeti yaptığı görülmektedir.

Hildegard kendi döneminin karmaşası içerisinde seslerini fazla duyuramayan hemcinslerine tavsiyelerde bulunmuş onları rahatlatmaya çalışmıştır. Örneğin o dönemin tanınan kadın mistiklerinden Schönau Elizabeth (1129-1164), kendi vizyonları hakkında Hildegard'a danışmıştır. ${ }^{81}$ Elizabeth gördügü vizyonu ile ilgili uzunca bir mektup yazmış, burada vecd halinde iken bir meleğin kendisine getirdiği haberlerden bahsetmiş ancak bu durumun çevresi tarafından şüphe ile karşılandığını söyleyerek ondan tavsiye almak istemiştir..$^{82}$ Hildegard ise gönderdiği mektupta görmüş olduğu vizyonların doğru olduğunu, Tanrı'nın bazen bu tarz aydınlanmalarla kendini insanlara açtığını bildirmiştir. Elizabeth'e bu gördüklerinin kendi nefsinden kaynaklanmadığı aksine Tanrı'nın inayeti ile olduğunu söyleyerek ona destek vermiştir. ${ }^{83}$

Hildegard, sadece kadınların değil erkeklerin de tavsiyeler aldığı bir isim olmuştur. İmparator Friedrich, Trier başkisposu Arnold gibi kişilerden gelen mektuplar buna örnektir. Toplumda saygın yerleri olan bu kişilerin Hildegard'ın tavsiyeleri kadar kahinliğinden de

80 Örneğin 20. mektup Odo adındaki birinin sıkıntılarından ve şeytanın vesveselerinden kurtulmak için "İsa'nın gelini" diye hitap ettiği Hildegard'a yazılmıştır. Baird, The Personal Correspondence of Hildegard of Bingen, 54. Hildegard gönderdiği cevapta onu teselli etmiş, ruhunun kurtuluşu için tavsiyelerde bulunmuştur. Yine başka bir mektupta gece kabuslarıyla sıkıntılar yaşayan bir rahibe gönderilmiş, bu da Hildegard'ın psikolojik danışmanlık yaptığını gösteren bir mistik olduğunu göstermektedir. Baird, The Personal Correspondence of Hildegard of Bingen, 62.

81 Newman, "Vision and Validation", 173.

82 Baird, The Personal Correspondence of Hildegard of Bingen, 78-79.

83 Baird, The Personal Correspondence of Hildegard of Bingen, 78-79. 
398 | H. TEMIZTÜRK / Kilise, Mistisizm ve Feodalite Perspektifinden Orta Çağlı Bir Hıristiyan Mistik: Bingenli Hildegard

yararlanmaya ve kendi gelecekleri adına bilgi almaya çalıştıkları dile getirilir. Bütün bu örnekler Hildegard'ın yaşadığı dönemde sıradan halk tabakalarından toplumun üst katmanlarındaki insanlara kadar değer verilen bir mistik olduğunu göstermektedir. Bu yüzden Hildegard Batı'da mistikten daha çok peygamberî özellikleri ile öne çıkan bir isim olarak kabul edilmiştir.

Hildegard'in dikkat çeken diğer bir yönü ise rahipler zümresinin reformu için çaba göstermesi, eleştiri ve tavsiyelerini eserlerinde ve vaazlarında dile getirmesidir. $O$, Trier sinodunda aldığı papalık onayı ile bu reform düşüncelerini daha güçlü bir şekilde dile getirmiştir. Hildegard, kilise önderlerinin davranışları ile halka örnek olamadıklarını ve onları Hiristiyanlığa uygun bir yaşam konusunda doğru yönlendiremediklerini dile getirmiştir. ${ }^{84}$ Hildegard'ın Cologne katedralinde hitap ettiği rahipler adına konuşan katedral sorumlusunun Tanrı'nın böyle kırılgan bir cinsiyet ile sırlarını ifşa etmesinin kendilerini şaşırttığını ifade etmesi dikkat çekmektedir. ${ }^{85}$ Kilise yöneticisi gönderdiği mektupta Tanrı'nın bu tercihine saygılı olduklarını zira Yuhanna 3/8' de ifade edildiği gibi bu durumu Tanrı'nın takdiri olarak gördüklerini ve Hildegard'ın dualarında yer almak istediklerini belirtmiştir. ${ }^{86}$ Ayrıca kendilerinin dünyevi meselelere daldığını, ruhsal meseleleri duyup görmediklerini itiraf ederek Hildegard'a hak vermiştir. Hildegard'in kendileri ile ilgili göreceği vizyonları dinleyeceklerini ve bu vizyonları mektupla kendilerine yazmalarını rica etmesi Hildegard'ın onlar üzerinde oldukça etkili olduğunu göstermektedir. ${ }^{87}$ Yine 1158 yılında yazılan Annales Palidenses adlı eserin yazarı da Tanrı'nın bu dönemde kırılgan ve narin olan bir cinsiyet olan kadınlarla kendi gücünü yansıttığını, Hildegard ve Elizabet gibi iki Tanrı hizmetkarının peygamberi bir ruhla dolu vizyonlarla donatıldığını ve insanları uyardığını ifade etmektedir. ${ }^{88}$

84 Flanagan, Secret of God-Writings of Hildegard of Bingen-, 2.

85 Baird, The Personal Correspondence of Hildegard of Bingen, 106-107.

86 Baird, The Personal Correspondence of Hildegard of Bingen, 106-107.

87 Baird, The Personal Correspondence of Hildegard of Bingen, 106-107.

88 Newman, "Vision and Validation", 173: Aktaran, Annales Palidenses, Monumenta Germanie Historica: Scriptores vol. 16 (Berlin: y.y., 1826), 90. 
Hildegard'ın yaşadığı dönem itibariyle kadınların dinî ve mistik alandaki rolleri konusunda sergilediği duruş dikkat çekicidir. Hildegard, kadının eğitim, yöneticilik ve vaaz gibi konularda sıkıntılar çektiği bir çağda yaşamıştır. ${ }^{89}$ Ancak buna rağmen kendi konventinde kadınlar için aldığ giyinme, süslenme, takı takma gibi kararlarla genel temayüllerin dışına çıkmıştır. Örneğin, rahibelerine siyah başlık takmalarını zorunlu hale getiren Tenkwid'e karşın Hildegard rahibelerine israrla beyaz rengi giyinmelerini söylemiştir. ${ }^{90}$ Bu örnek bize Hildegard'ın "İsa' nın gelinleri" olarak yorumladığı rahibelere sağladığı mistik bir açılımdır. Fakat Hildegard'ın eserlerinde Havva'nın günahkarlığı konusunda geleneksel görüşü paylaştığı, evde, toplumsal hayatta hatta cinsellik konusunda bile erkeğin üstünlüğü kabul ettiği görülmektedir. Bu nedenle Hildegard'1 bir Ortaçağ feministi olarak görmek mümkün değildir. Bu hem metinler açısından mümkün değildir hem de anakronizm tehlikesine düşme anlamina gelmektedir.

Hildegard'ın Pavlus ve Augustinus'un kadınlara yönelik sert çizgilerini esnettiği söylenebilir. Kadınların günahkâr yapısına rağmen Tanrı tarafından seçildiğini zira erkeklerin verilen emaneti yerine getiremediğini ifade etmesi dikkat çekmektedir. Bu açıdan Hildegard'ın, gelenekteki kadının konumundan radikal bir kopuş sergilemediği görülür. Diğer bir ifadeyle onun, tarihten kendi dönemine miras kalan kadının zayıflığı meselesini kabullendiği ama yine de Tanrı'nın kendisine verdiği özel hediyelerle bu olumsuz mirasın dışına çıkmaya çalıştığ1 söylenebilir. Biyolojik ve psikolojik farklılıkları yadsımadan cinsiyetlerin Tanrı katında manevi olarak eşit değere sahip olduğu ve birbirini tamamladıkları düşüncesi Bingenli Hildegard'ı çağının mistiklerinden ayırmaktadır. Buna rağmen Hildegard'1 modern bir feminist lider gözüyle değerlendiren bakış açısını yansıtan iddialar karşısında dikkatli olmak gerekir. Zira Hildegard'ın kadın konusundaki görüşleri tamamen gelenek karşıtlığı olarak görülmemelidir. Hatta onun kendi dönemindeki kadınların durumları ile nadiren ilgilendiğini, kabul görmüş normların

89 Minnis ve Voaden, "'Introduction"'", 2.

90 Akın, Orta Çă̆dan Bilge Bir Kadın Bingenli Azize Hildegard, 89. 
400 | H. TEMIZTÜRK / Kilise, Mistisizm ve Feodalite Perspektifinden Orta Çağlı Bir Hıristiyan Mistik: Bingenli Hildegard

üzerine gitmediğini bu açından tam bir gelenek koruyucusu olduğunu düşünen araştırmacilar mevcuttur. ${ }^{91}$

Ayrıca Hildegard'ın eserlerinde kadın ve erkeğin cinsel doğalarına dair yaptığı açıklamalar yaşadığı çağın normları düşünüldüğünde oldukça sıra dışıdır. Bu düşüncelerini sadece medikal bilgilerin ışığında sunmamış kadın ve erkeğin seksüel doğalarını, fiziksel ve biyolojik farklılarını da ayrıca dile getirmiştir. ${ }^{92}$ Özellikle Scivias adlı eserinin farklı yerlerinde erkek ve kadının cinsel dürtülerini, hangi yiyecek ve içeceklerin cinsel güce iyi geldiğini ifade etmesi dikkat çekicidir. Bunun yanında âdet sancısı çeken, doğum sonrası acılar yaşayan kadınların durumlarını ayrıntılı bir şekilde tahlil edip, tedaviler de sunmuştur. Dolayısıyla onun cinselliği sadece çocuk sahibi olmak için gerekli gören Tertullanius, Augustinus gibi Kilise babalarmdan ve Kilise'nin düşüncelerinden farklı bir yol izlediği söylenebilir.

\subsection{Mistik Huristiyanlığa Etkisi}

Hildegard'ın geliştirmiş olduğu mistik düşünceler kendisinden sonra gelen mistiklere yol gösterici olmuş ve kaynaklık etmiştir. Özellikle onun Book of Divine Works adlı kitabında vurgulamış olduğu düşünceler, XII. yüzyılda Bernardus Silvestris gibi düşünürlerin geliştirdiği spekülatif teolojiye $^{93}$ kaynaklık teşkil etmiştir.94 Yine Hildegard'ın eserlerinde kullanmış olduğu sembolik teolojinin oldukça kuvvetli olduğu bilinmektedir. Öyle ki Hildegard'ın çağdaşları olan Lilleli Alan, Aziz Viktorlu Hugh ve Bernardus Silvestris'den sembolik teoloji dilini kullanma konusunda daha güçlü bir yapısı olduğu dile getirilmiştir. ${ }^{95}$ Hildegard'ın sembolik teolojiyi uygulaması açısından kendisinden sonra gelişecek bu türe zemin hazırladığ söylenebilir.

91 Bernhard W. Scholz, "Hildegard von Bingen on the Nature of Woman", American Benedictine Review 31 (1980): 62.

92 Scholz, "Hildegard von Bingen on the Nature of Woman", 382.

93 İnancın doğasını anlamaya yönelik çabalardan birisi olan spekülatif teoloji, umut, adalet, ilim, irade ve ilahi aşk üzerine odaklı bir teoloji anlayışıdır. Bk. Tibor Horvath, Thinking about Faith: Speculative Theology (Motreal: McGill-Quenn's University Press, 2006), 8.

94 Dickens, The Female Mystic, 29.

95 Dickens, The Female Mystic, 35. 
Hildegard'ın kendisinden sonraya bıraktığı diğer bir katkı ise Tanrı'nın gücü, bilgeliğine dair kullandığı feminen ifadelerdir. Newman, Kilise'nin, Kutsal Ruh'un, kozmosun ve kurtuluşun kadın doğası üzerinden yani feminen imgelerle açılanması anlamına gelen bilgelik geleneğinin (sapiential tradition) Hildegard tarafından mistik Hıristiyanlığa miras bırakıldığını söylemiştir. ${ }^{96}$ Hildegard'ın feminen bir tarzda ele aldığı bu "bilgelik", "Tanrı aşkı" gibi kavramların kendisinden sonraki Sisteryan geleneğinde devam ettirildiği görülmektedir. ${ }^{97}$

Hildegard, kadın mistikler arasında yazdıkları ile kalıcı olmayı başarmış ve kendinden önce yaşayan diğer mistik kadınlara nazaran daha tanınır bir isim olmuştur. Örneğin Egeria, Perpetua, Baudonivia, Dhuoda ve Hrotsvitha gibi mistik kadınlar düşüncelerini yazıya geçirse bile tarih sahnesinden silinip gitmişlerdir. ${ }^{98}$ Ayrıca Hildegard, kadınlara özgü manastır kurması ve manastır kurallarını revize etmesiyle kendisinden sonra gelişecek kadın mistik hareketlerine öncülük etmiştir. Örneğin Schönaulu Elizabeth kendi mistik düşüncelerinin oluşumunda Hildegard gibi bir rol-model olmasının avantajlarını yaşamıştır. ${ }^{99}$ Kadının kırılganlığı meselesi üzerinden Tanrı'nın sırlarını kadınlara açtığı düşüncesi kendisinden sonra Schönaulu Elizabet tarafından benimsenmiştir. ${ }^{100}$ Yine onun Antwerpli Hadewijh, Magdeburglu Mechthild, Haianutlu Margurite Porete, Nazeretli Beatrice gibi isimlerden oluşan ve "Beguineler" olarak adlandırılan mistik kadınlar için bir prototip olduğu düşünülmektedir. ${ }^{101} \mathrm{Bu}$ mistikler de Hildegard gibi Kilise'ye ayrımcılık, dinî görevlerin satılması, entelektüel çoraklık ve Hıristiyanlığa uygun yaşam konularında reform yapma çağrısı yapmışlardır. Böylece Hildegard'ın, kendisinden sonra gelecek Beguineler hareketinin yenilik ve canlanma adına yaptıkları reform çağrısına öncülük ettiği söylenebilir.

Hildegard eserlerinde vizyonlarında kullandığı minyatürler ise imge ve illüstrasyon alanında Hıristiyan sanatına katkıda bulunmuştur.

\footnotetext{
96 Newman, “Preface (1997)”, Sister of Wisdom, 21.

97 Dickens, The Female Mystic, 36.

98 Newman, "Introduction", Scivias, 9.

99 Newman, Sister of Wisdom, 37.

100 Newman, Sister of Wisdom, 36.

101 Brunn-Burgard, Women Mystics in Medieval Europe, 12.
} 
402 | H. TEMIZTÜRK / Kilise, Mistisizm ve Feodalite Perspektifinden Orta Çağlı Bir Hiristiyan Mistik: Bingenli Hildegard

Her ne kadar vizyonlara eklemlenen bu minyatürlerin bizzat Hildegard'ın çizimleri olmasa da onun öncülügünde yapıldığ 1 düşünülmektedir. ${ }^{102}$ Özellikle apokaliptik vizyonların başarılı bir şekilde minyatüre dönüştürülmesi Hıristiyanlıkta ikonografi sanatından sonra resim alanında da gelişmesine ön ayak olmuştur. Bu açıdan Hildegard'ın Liebanalı Beatus'dan sonra apokaliptik illüstrasyon geleneğinde çok önemli bir yer teşkil ettiği düşünülmektedir. ${ }^{103}$

Diğer taraftan bugün bile kullanılan Kilise müziklerini bestelemesi onun günümüze kadar olan etkisinin göstergesi ve kalıcı oluşunun sebeplerinden birisidir. The Symphony of the Harmony of Celestial Revelation olarak bilinen eseri ile, Hildegard yetmişin üzerinde ilahi, antiphoni (karşılıklı ilahi okuma usulü), vercisle (bent okuma) denen müzikli ezgileri Hıristiyan literatürüne kazandırmıştır. Hildegard'ın kendisinden önce çok kısır olan bu ezgi türünü canlandırdığı ve bir kült haline getirdiği söylenebilir.

\section{Sonuç}

Bingenli Hildegard, dinsel tartışmaların, sosyal ve ekonomik dönüşümlerin yaşandığı bir dönemde yaşamıştır. Çıktığı vaaz turları ve papa tarafından onaylanan vizyonları ile yaşadığı döneme etki etmiş bir mistik olan Hildegard, 19. yüzyıldan itibaren mistisizmin etkisini kaybetmesiyle göz ardı edilmiştir. Zira Aydınlanma dönemi ile başlayan dinî düşüncelerin rasyonel bir bakış açısı ile değerlendirilmesi sürecinde mistik gelenekler de tartışılmaya başlanmıştır. Fakat zamanla mistisizm dünya üzerinde etkili olmaya başlamış, Kabala okulları, tasavvuf ekolleri yanında Hıristiyan mistisizmi de yeniden canlanmıştır. İşte Orta Çağlı bir mistik olan Bingenli Hildegard da son yirmi yıl içerisinde Batı' da yeniden gündem olmuştur. Müzikten, botaniğe, fizikten mistisizme kadar yazdığ eserler tercüme edilmeye, edisyon ve kritikleriyle beraber yayımlanmaya başlanmıştır.

Hildegard, 1098 yılında Almanya'nın Mainz piskoposluğuna bağlı Bermersheim olarak bilinen yerde ailesinin onuncu çocuğu olarak doğmuştur. Bingen ismi ise doğduğu yere değil sadece kadınlara ait bir

102 Richard K. Emmerson, “The Representation of Antichrist in Hildegard of Bingen's Scivias: Image, Word, Commentary and Visionary Experience", Gesta 41/2 (2002): 98.

103 Emmerson, "The Representation of Antichrist in Hildegard of Bingen's Scivias: Image, Word, Commentary and Visionary Experience", 98. 
manastır kurduğu Ren nehri bölgesindeki Bingen' e nispetle verilmiştir. Zaman zaman Hildegard'ın "Ren'li Mistik ya da Kahin" olarak adlandirılması da bu nedenledir. Dindar bir aileye mensup olan Hildegard'ın erken yaşlarda manastıra verildiği bilinmektedir. Hildegard, erkek ve kadın konventlerinden oluşan ve çifte manastır statüsünde olan Aziz Disibod manastırında 1112-1150 yılları arasında kalmıştır. Kadınlar konventinin lideri olan Jutta'nın ölümünden sonra onun yerine geçen Hildegard daha sonra sadece kadınlara ait bir manastır kurma ideali ile Aziz Rupert manastırına taşınmıştır.

Hildegard hem eserleriyle hem de yaşadığ dönemdeki etkinliğiyle Hıristiyanlık tarihine ve Hıristiyan düşüncesine katkılarda bulunmuştur. Makalede Hildegard'ın hem bu yönü hem de düşüncelerine etki etmiş olan soyluluk ve feodalite gibi hususlar tartışılmıştır.

Hildegard Orta Çağlı bir mistik kadın olarak çağın koşullarından etkilenmiş ancak yine de birçok çağdaşı kadına göre daha ayrıcalıklı bir yere sahip olmuştur. Bunun sebeplerinden birisi onun Papa'dan İmparatora, mistiklerden soylulara kadar geniş bir destekçisinin olmasıdır. Bu durum onun vizyonlarının Kilise kurumu tarafından onaylanmasına yardım etmiştir. Böylece gördüğü vizyonları kabul edilen bir mistiğin ve çoğu zaman göz ardı edilen kadın zümresinin bir temsilcisi olarak Hildegard, düşüncelerini ve eleştirini sağlam bir zemine oturtmuştur. Kendi meşruiyetini dünyevi destekçileri ile sağlayan Hildegard'ın ortodoksi sınırlarında kalarak Kilise kurumlarını eleştirdiği söylenebilir. Hildegard'ın manastıra ilk kabulü sırasında etkili olan soyluluk nişanesinin yine bu farklı manastıra taşınma sürecinde etkili olduğu görülmektedir. Çünkü yeni manastırın kurulması sırasında gerekli lojistik desteğin sağlanması kadar eski manastır yöneticilerinin onun ayrılığına karşı durmaları da onun soyluluk bağı ile aşılmıştır.

Hildegard'ın kendisinden sonraya bıraktığı diğer bir katkı Tanrı'nın gücü, bilgeliğine dair kullandığı feminen ifadelerdir. Hildegard'ın Kilise'yi, Kutsal Ruh'u, kozmosu ve kurtuluşu feminen imgelerle açıklanması anlamına gelen bilgelik geleneğini (sapiential tradition) mistik Hıristiyanlığa eklemlendiği söylenebilir. Diğer taraftan bugün bile kullanılan Kilise müziklerini bestelemesi onun günümüze kadar olan etkisinin göstergesi ve kalıcı oluşunun sebeplerinden birisidir. Hildegard'ın erkek manastırından bağımsız bir hayatı seçmesi, rahibeler 
404 | H. TEMIZTÜRK / Kilise, Mistisizm ve Feodalite Perspektifinden Orta Çağlı Bir Hıristiyan Mistik: Bingenli Hildegard

konvetinin magistrası olması, vaaz turları ile halka ve rahiplere hitabı, kilise müzikleri ve tıbbi bilgilere dair kitaplar yazması, eserlerini resimlerle zenginleştirmesi onun erken Rönesans'ının temsilcisi şeklinde yorumlanmasına sebep olmuştur. Modern dönemde Hildegard ile ilgili tartışmaların başında özellikle feminist araştırmacılar tarafından onun "Orta Çağlı bir feminist" olarak görülmesi problemidir. Ancak Hildegard'ı bir feminist lider olarak değerlendiren bu bakış karşısında dikkatli olmak gerekir. Zira mistik kadın olarak kendi manastırında rahibelere süslenme izni vermesi, evlilik ve cinsellik gibi konularda getirdiği yenilikler sebebiyle "Orta Çağ feministi" ifadesini vermek mümkün gibi gözükse de onun eserleri incelendiğinde bu kabulün hatalı bir yaklaşım olduğunu düşünmekteyiz. Zira Hildegard'ın kadın konusundaki görüşleri tamamen gelenek karşıtlığı olarak görülmemelidir. Hatta onun kendi dönemindeki kadınların durumları ile nadiren ilgilendiğini, kabul görmüş normların üzerine gitmediğini bu açıdan geleneği muhafaza ettiğini söylemek mümkündür.

\section{Kaynakça}

Abbey of Arts. "Hildegard of Bingen and the Greening Power of God: A Pilgrimage in Germany". Erişim: 01.03.2018. https://abbeyofthearts.com/programs/live-classes-andretreats/hildegardpilgrimage/.

Akın, Haydar. Ortaçağdan Bilge Bir Kadın Bingenli Azize Hildegard. İstanbul: Dharma Yayınları, 2005.

Baird, L. Joseph. The Personal Correspondence of Hildegard of Bingen-Selected Letters with an Introduction and Commentary. Oxford: Oxford Universty Press, 1994.

Behind The Name. "Hildegard". Erişim: 10.12.2017. http://www.behindthename.com/name/hildegard.

Brunn, Emilie. Zum-Georgette Epiney Burgard, Women Mystics in Medieval Europe, (İng.) Trc. Sheila Hughes. New York: Paragon House, 1989.

Butcher, Carmen Acevedo. St. Hildegard of Bingen-Doctor of the Church: A Spiritual Reader. Massachusetts: Paraclete Press, 2013.

Dickens, Andrea Janelle. The Female Mystic-Great Women Thinkers of the Middle Ages-. London: I. B. Tauris \& Co Ltd, 2009. 
Dronke, Peter. Poetic Individuality in the Middle Ages. Oxford: Oxford University Press, 1970.

Emmerson, Richard K. "The Representation of Antichrist in Hildegard of Bingen's Scivias: Image, Word, Commentary and Visionary Experience". Gesta 41/2 (2002): 95-110.

Evangelisti, Silvia. Nuns-A History of Convent Life 1450-1700-. Oxford: Oxford University Press, 2007.

Feiss, Hugh. "Introduction". Hildegard of Bingen, Two Hagiographies: Vita Sancti Rupperti Confessoris and Vita Sancti Dysibodi Episcopi. Ed. Christopher P. Evans - Hugh Feiss. Leuven: Peeters Publishers, 2010.

Flanagan, Sabina. Secret of God, Writings of Hildegard of Bingen-Selected and Translated from the Latin-. Boston: Shambala, 1996.

Fulbrook, Mary. Almanya'nın Kısa Tarihi. Trc. Sabri Gürses. 2. Baskı. İstanbul: Boğaziçi Üniversitesi Yayınları, 2011.

Gaynor, Frank. Dictionary of Mysticism. London: Wildwood House, 1974. Genç, Özlem. “Orta Çă̆ Avrupasında Kadın”. Orta Çă̆g'da Kadın. Ed. Altan Çetin. 241-297. Ankara: Lotus Yayınevi, 2011.

Gül, Muammer. Orta Çă̆ Avrupa Tarihi. İstanbul: Bilge Kültür Sanat, 2009. Hildegard. Book of Divine Works with Letters and Songs. Ed. Matthew Fox. Sante Fe: Bear\&Company, 1987.

Hildegard. The Book of the Rewards of Life: Liber Vitae Meritorum, Trc. (Ing). Bruce W. Hozeski. Oxford: Oxford University Press, 1995.

Hildegard. The Letters of Hildegard of Bingen, Trc. (İng.) Joseph L. Baird Radd K. Ehrman. 3 Cilt. Oxford: Oxford Universty Press, 1994.

Hildegard. Two Hagiographies: Vita Sancti Rupperti Confessoris and Vita Sancti Dysibodi Episcopi. Ed. Christopher P. Evans - Hugh Feiss. Leuven: Peeters Publishers, 2010.

Hildegard. Scivias. Trc. (İng) Mother Columba Hart - Jane Bishop. New York: Paulist Press, 1990.

Higley, Saray. Hildegard of Bingen's Unknown Language: An Edition, Translation, and Discussion. New York: Mac Millian Press, 2007.

Horvath, Tibor. Thinking about Faith: Speculative Theology. Motreal: McGillQuenn's University Press, 2006. 
406 | H. TEMIZTÜRK / Kilise, Mistisizm ve Feodalite Perspektifinden Orta Çağlı Bir Hıristiyan Mistik: Bingenli Hildegard

Kienzle, Beverly M. "Introduction". A companion to Hildegard of Bingen. Ed. Beverly Mayne Kienzle - Debra L. Stoudt - George Ferzoco. LeidenBoston: Brill, 2014.

Kutsal Kitap, Eski ve Yeni antlaşma (Tevrat, Zebur, İncil). İstanbul: Kitab1 Mukaddes Şirketi, 2001.

Le Goff, Jacques. Orta Çă̆ Batı Uygarlığı. Trc. Hanife Güven - Uğur Güven. Ankara: Doğu Batı Yayınları, 2017.

Martin, Sean. the Cathars. New York: Thunder's Mouth Press, 2005.

Minnis, Alastair. "Religious Roles: Public And Private". Medieval Holy Women in the Christian Tradition c. 1100-c. 1500. Ed. Alastair Minnis

- Rosalynn Voaden. Belgium: Brepols Publishers n.v., 2010.

Newman, Barbara. Sister of Wisdom- St. Hildegard's Theology of The Feminine-. California: University of California Press, 1997.

Newman, Barbara. "Vision and Validation". Church History 54/2 (Jun., 1985), 163-175.

Palidenses, Annales. Monumenta Germanie Historica: Scriptores. Vol. 16. (Berlin: y.y., 1826).

Pitra, Joannes-Baptiste. Anelecta Sacra. Monte Cassino, 1882.

Proquest. "ProQuest Dissertations \& Theses Global". Erişim: 01.03.2018.https://search.proquest.com/pqdtglobal/results/25C6A4 3E3EA94D74PQ/1?accountid=7412.

Scholz, Bernhard W. "Hildegard von Bingen on the Nature of Woman", American Benedictine Review 31 (1980): 361-384.

Silvas, Anna. Jutta and Hildegard: the Biographical Sources-Medieval Women: Texts and Contexts. Pennsylvania: Pennsylvania State Universty Press, 1999.

Spiritual Travels. "The Hildegard of Bingen Trail in Germany". Erişim:01.03.2018. https://www.spiritualtravels.info/articles2/europe-2/the-hildegard-of-bingen-trail-in germany/http://www.sdiworld.org/educational-event/interfaithpilgrimage-germany-footsteps-hildegard-bingen,

Wende, Peter. A History of Germany. New York: Macmillan, 2005. 
H. TEMIZTÜRK / A Christian Mystic in the Middle Age: Hildegard of Bingen -From Perspective Church, Mysticism and Feodality | 407

\section{Ekler}

Ek-1 Hildegard'ın Yaşadığı Yerler ve Kaldığı Manastırlar

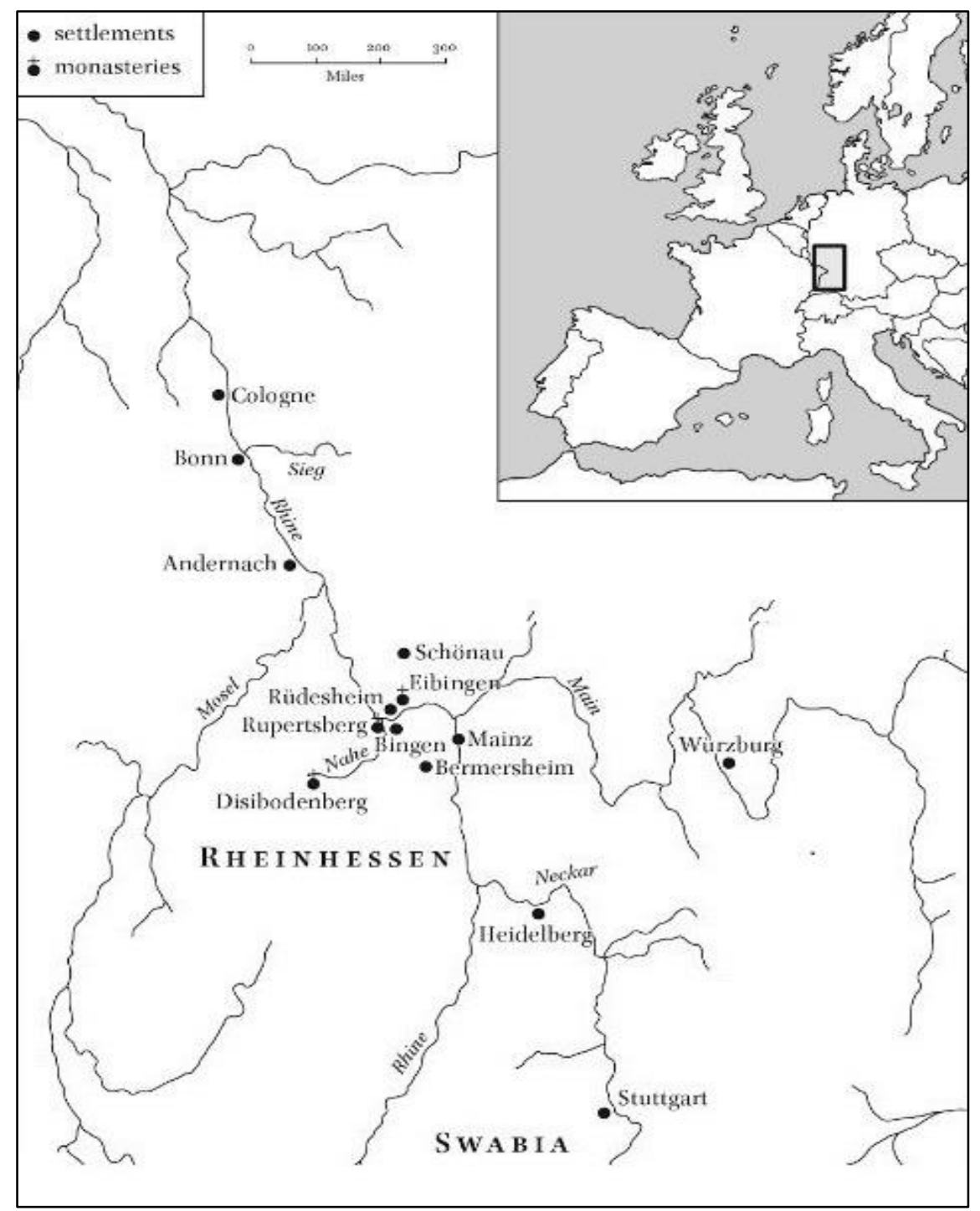

Ek 1 için bk. A Companion to Hildegard of Bingen, ed. Beverly Mayne Kienzle, Debra L. Stoudt and George Ferzoco (Leiden. Boston: Brill, 2014), xix. 
408 | H. TEMIZTÜRK / Kilise, Mistisizm ve Feodalite Perspektifinden Orta Çağlı Bir Hıristiyan Mistik: Bingenli Hildegard

Ek-2- Vaaz Turlarında Bulunduğu Yerler

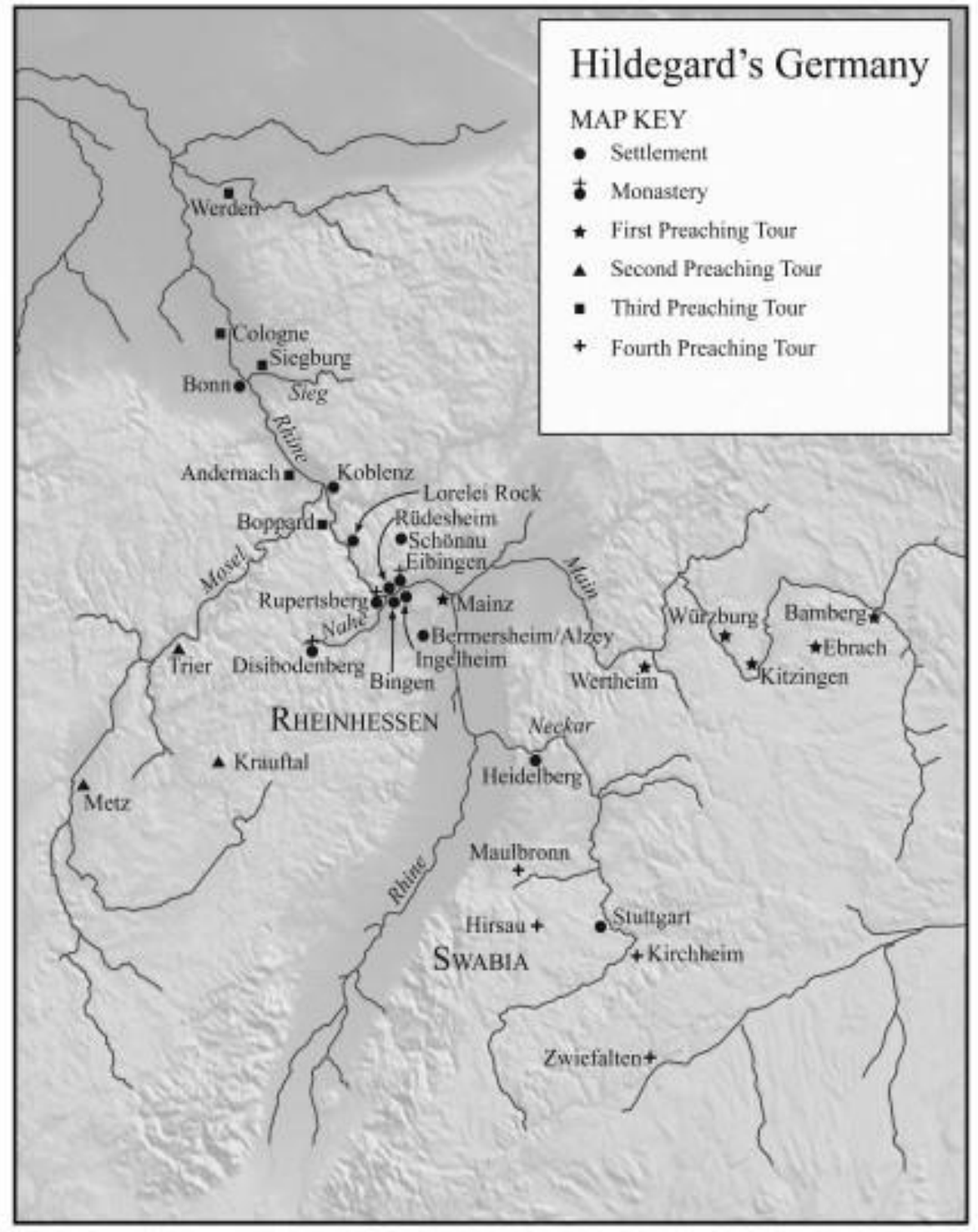

Ek-2 için bk. Carmen Acevedo Butcher, St. Hildegard of BingenDoctor of the Church: A Spiritual Reader (Massachusetts: Paraclete Press, 2013), viii. 